\title{
Abolishing the Common Law Offence of Keeping a Disorderly House
}

\author{
Graham McBain ${ }^{1,2}$ \\ ${ }^{1}$ Peterhouse, Cambridge, UK \\ ${ }^{2}$ Harvard Law School, USA \\ Correspondence: Graham McBain, 21 Millmead Terrace, Guildford, Surrey GU2 4AT, UK. E-mail: \\ gsmcbain@aol.com
}

Received: December 5, 2014 Accepted: December 22, 2014 Online Published: May 27, 2015

doi:10.5539/jpl.v8n2p17 URL: http://dx.doi.org/10.5539/jpl.v8n2p17

\section{Introduction}

A previous article has reviewed the law in relation to escape, prison breach and rescue ${ }^{1}$ which, it argues, should now be made statutory offences. This article looks at another common law offence - one of 'keeping a disorderly house'- which, it is asserted, should be abolished, being obsolete.

In medieval times - especially in London - this crime was designed to suppress brothels as well as other sexual conduct (such as adultery and fornication) which it was deemed appropriate for the criminal law to punish. Thus, in respect of the latter, it appears it was a London custom that a constable - on receipt of an information - had the legal right to enter a house where a person was suspected of committing adultery or fornication and 'carry them to prison. ${ }^{2}$

- From 'disorderly house' being a reference to a place where socially unacceptable sexual activity was carried on, the concept was extended to cover common gaming houses. Also, to play houses (theatres), ${ }^{3}$ common inns and 'common' houses (that is, ones to which the public had access) where cock-fights were held;

- Since these places also tended to be venues for illicit sexual activity, it is understandable how they came to be embraced within the concept. That said, it also seems clear this extended definition of a 'disorderly house' did not derive from the caselaw. Rather, it likely derived (in essence) from William Hawkins. In his Treatise on the Pleas of the Crown (1716-21) $)^{4}$ under the heading 'Of Common Nuisances' he 'packaged' together brothels, gaming houses etc. and later legal writers followed suit, closely allying them with 'disorderly houses'.

Whether or not this was appropriate in the past, today, specific legislation governs casinos, theatres, brothels and sexual entertainment venues. Thus, it is not necessary (or appropriate) to include such offences within the definition of a 'disorderly house'. The inclusion of common inns is also unnecessary since the common law offence of a common innkeeper refusing to provide board and lodging was (and is) a separate offence. ${ }^{5}$ As a result, this article will argue for the abolition of the offence of keeping a disorderly house. ${ }^{6}$ In analysing this offence, regard may be had to the following legal texts:

\footnotetext{
${ }^{1}$ GS McBain, Modernising the Law on Escape, Prison Breach and Rescue (2014) Review of European Studies, vol 6, no 4, pp 147-73.

${ }^{2}$ See Gylys $v$ Watterkyn (1486) discussed in 5(a). There also seems to have been a London custom that a constable - on receiving an information that a man in his ward might be frequenting a brothel - could enter the house and arrest the offender for breach of the peace, providing the man was in such company. See $\mathrm{n} 97$.

${ }^{3}$ Also included were stages where 'rope dancers' performed. This was a reference to acrobats, tight rope walkers and other circus performers who often used a playhouse stage to perform on. See n 158.

${ }^{4}$ W Hawkins, A Treatise on Pleas of the Crown (1st ed, 1716-21, last ed $\left(8^{\text {th }}\right)$ 1824). The work of Hawkins was very popular in the period 1716-1824. Indeed, it was the standard work on criminal law until superceded by Russell, see $n$ 14. The tendency of Hawkins to gather various common law offences together may also be seen with respect to other crimes such as 'Contempt of the Sovereign', which is discussed in GS McBain, Abolishing some Obsolete Common Law Crimes (2009) 20 King's LJ, pp 98-109.

${ }^{5}$ See McBain, n 4, pp 90-8.

${ }^{6}$ As will be seen, the common law offence of keeping a disorderly house did not cover matters such as noise, rowdiness, violence etc. In any case, these are better dealt with, today, by reference to noise legislation and other more specific criminal offences such as assault, battery etc.
} 
- $\quad$ H Bracton, On the Law and Customs of England (c. 1240); ${ }^{7}$

- Fleta (c. 1290); ${ }^{8}$

- The Mirror of Justices (c. 1290); ${ }^{9}$

- $\quad$ E Coke, Institutes of the Laws of England (1628-41); ${ }^{10}$

- W Hawkins, A Treatise of the Pleas of the Crown (1716-1824); ${ }^{11}$

- M Hale, The History of the Pleas of the Crown (published 1736, written 1640's); ${ }^{12}$

- W Blackstone, Commentaries on the Laws of England (1765-9); ${ }^{13}$

- WO Russell, A Treatise on Crimes and Misdemeanors (1819-1964); ${ }^{14}$

- W Archbold, Criminal Pleading, Evidence and Practice (1822-2014); ${ }^{15}$

- Halsbury, Laws of England. ${ }^{16}$

It may be noted, in respect of this offence, that - apart from Archbold, Halsbury and Blackstone's Criminal Practice 17 - modern criminal texts contain no (or very little) analysis of it. ${ }^{18}$ However, reference may be made to various Abridgments, major and minor, viz.

- $\quad$ N Statham, Abridgment of the Law (c. 1490); ${ }^{19}$

- A Fitzherbert, La Graunde Abridgment ( ${ }^{\text {rd }}$ ed, 1577); ${ }^{20}$

- $\quad$ R Brooke, La Graunde Abridgment (1586); ${ }^{21}$

- H Rolle, Abridgment des plusieurs Cases et Resolutions del Common Ley (1668),22

- W Hughes, Grand Abridgment of the Law (1660-3); ${ }^{23}$

- W Sheppard, Grand Abridgment of the Common and Statute Law of England (1675); ${ }^{24}$

\footnotetext{
${ }^{7}$ H Bracton (trans Thorne), On the Law and Customs of England c.1240 (Cambridge UP, 1968-76). Bracton is now online, see bracton.law.harvard.edu

${ }^{8}$ Fleta, see Selden Society ('SS'), vols 72, $89 \& 99$.

${ }^{9}$ The Mirror of Justices, SS, vol 7.

${ }^{10}$ E Coke, Institutes of the Laws of England (W Clarke \& Sons, London, last ed, 1824).

${ }^{11}$ See $\mathrm{n} 4$.

${ }^{12}$ M Hale, The History of the Pleas of the Crown (printed for E \& R Nutt \& R Gosling, 1736).

${ }^{13}$ W Blackstone, Commentaries on the Laws of England (Oxford, Clarendon Press, $1^{\text {st }}$ ed, 1765-9, University of Chicago Press rep 1979).

${ }^{14}$ WO Russell, A Treatise on Crimes and Misdemeanors $\left(1^{\text {st }} \mathrm{ed}, 1819\right.$; last ed, $\left.12^{\text {th }} \mathrm{ed}, 1964\right)$.

${ }^{15}$ W Archbold, Criminal Pleading, Evidence and Practice (Sweet \& Maxwell, 2014). See also JF Archbold, A Summary of the Law relative to Pleading and Evidence in Criminal Cases (London, 1822, being the $1^{\text {st }} \mathrm{ed}$ ).

${ }^{16}$ Halsbury, Laws of England (5th ed, with updates).

${ }^{17}$ Blackstone's Criminal Practice 2013 (eds A Hooper \& D Ormerod)('Blackstone CP'). See also Archbold, Magistrates' Courts Criminal Procedure ('Archbold Procedure').

${ }^{18}$ See, for example: (a) C McAlhone \& R Huxley-Binns, Criminal Law. The Fundamentals (3rd ed, 2013); (b) MJ Allen, Textbook on Criminal Law (12 ${ }^{\text {th }}$ ed, 2013); (c) A Ashworth \& J Horder, Principles of Criminal Law ( $7^{\text {th }}$ ed, 2013); (d) R Card et al, Criminal Law (20 ${ }^{\text {th }}$ ed, 2012); (e) CMV Clarkson \& HM Keating, Criminal Law, Text and Materials ( $7^{\text {th }}$ ed, 2010); (f) C Elliott \& F Quinn, Criminal Law ( $8^{\text {th }}$ ed, 2010); (g) R Heaton, Criminal Law ( $2^{\text {nd }}$ ed, 2006); (h) J Herring, Criminal Law ( $8^{\text {th }}$ ed, 2013); (i) M Jefferson, Criminal Law (9 $9^{\text {th }}$ ed, 2009); (j) Lacey, Wells \& Quick, Reconstructing Criminal Law. Text and Materials ( $\left.4^{\text {th }} \mathrm{ed}, 2010\right) ;(\mathrm{k}) \mathrm{J}$ Loveless, Complete Criminal Law. Text. Cases and Materials ( $3^{\text {rd }}$ ed, 2012); (1) N Padfield, Criminal Law ( $7^{\text {th }}$ ed, 2010); (m) A Reed \& B Fitzpatrick, Criminal Law (4 ${ }^{\text {th }}$ ed, 2009); (n) AP Simester, Simester \& Sullivan's Criminal Law: Theory and Doctrine (5 ${ }^{\text {th }}$ ed, 2013); (o) D Ormerod, Smith \& Hogan's Criminal Law (13 ${ }^{\text {th }}$ ed, 2011); (p) DJ Baker, Glanville Williams Textbook of Criminal Law ( $3^{\text {rd }}$ ed, 2012); (q) MJ Allen \& S Cooper, Elliott \& Woods' Cases and Materials on Criminal Law $\left(11^{\text {th }}\right.$ ed, 2013); (r) M Molan, Cases and Materials on Criminal Law $\left(4^{\text {th }} \mathrm{ed}, 2008\right) ;(\mathrm{s}) \mathrm{J}$ Martin \& T Storey, Unlocking Criminal Law $\left(3^{\text {rd }}\right.$ ed, 2010); (t) P Hungerford-Welch \& A Taylor, Sourcebook on Criminal Law (1997); (u) M Molan et al, Bloy \& Parry's Principles of Criminal Law ( $4^{\text {th }}$ ed, 2000); (v) W Wilson, Criminal Law ( $4^{\text {th }}$ ed, 2011). For older $20^{\text {th }}$ century texts, see JW Cecil Turner, Kenny's Outlines of Criminal Law $\left(19^{\text {th }}\right.$ ed, 1966) and R Cross \& PA Jones, An Introduction to Criminal Law ( $2^{\text {nd }}$ ed, 1949).

${ }^{19}$ N Statham, Abridgment of the Law (Pynson, c. 1490). This has been reprinted by the Law Book Exchange. For a translation, see MC Klingelsmith, Statham's Abridgment of the Law (Boston Book Company, 1915).

${ }^{20}$ A Fitzherbert, La Graunde Abridgment (Tottell, $3^{\text {rd }}$ ed 1577). The $3^{\text {rd }}$ edition is generally preferred. This has been reprinted by the Law Book Exchange.

${ }^{21}$ R Brooke, La Graunde Abridgment (Tottell, 1586).

${ }^{22} \mathrm{H}$ Rolle, Abridgment des plusieurs Cases et Resolutions del Common Ley (A Crooke et al, 1668).

${ }^{23}$ W Hughes, Grand Abridgment of the Law (Henry Twyford etc al, 1660-3). This has been reprinted by the Law Book Exchange.
} 
- W Nelson, Abridgment of the Common Law (1725-6); ${ }^{25}$

- $\quad$ M Bacon, New Abridgment of the Law ( $5^{\text {th }}$ ed, 1798); ${ }^{26}$

- $\quad$ E Viner, A General Abridgment of the Law and Equity $\left(1^{\text {st }}\right.$ ed, 1741-57); ${ }^{27}$

- J Comyns, Digest of the Laws of England (last ed, 1822). ${ }^{28}$

In conclusion, this article reviews the history - and legal nature - of the common law offence of keeping a disorderly house. Also, it proposes its abolition.

\section{Keeping a Disorderly House - The Modern Offence}

Prior to considering the early law, reference may be made to the modern incarnation of this offence. Archbold (2014) states: ${ }^{29}$

A disorderly house is one which is not regulated by the restraints of morality and which is so conducted as to violate law and good order. There must be an element of 'open house' but it does not need to be open to the public at large. ${ }^{30}$ A disorderly house may amount to a common nuisance but it is not an essential ingredient of the offence of keeping a disorderly house.

Where indecent performances or exhibitions are alleged as rendering the premises a disorderly house, it must be proved that matters are there performed or exhibited of such a character that their performance or exhibition in a place of common resort (a) amounts to an outrage of public decency, or (b) tends to corrupt or deprave, or (c) is otherwise calculated to injure the public interest, so as to call for condemnation and punishment. These ingredients should not, however, be regarded as mutually exclusive and a performance may well offend in all three respects. ${ }^{31}$ (wording divided for ease of reference)

As may be seen, Archbold refers to sexual disorder in particular. In so doing this reflects the true nature of this offence in early times. Thus, one will now consider the early law.

\section{Keeping a Disorderly House: The Medieval Position - Inns}

Both before the Norman Conquest of 1066 - as well as for a couple of centuries after it - the criminal law was rudimentary in nature. Further, the control of the royal courts over crime was scant, both geographically and with regard to minor public order offences. ${ }^{32}$ Finally, there were only a limited number of crimes - most relating to physical assault in one form or another.

- As to the society in which they were perpetrated, both in Anglo-Saxon and in Anglo-Norman times, there were few cities in England, the population being pre-dominantly located in small towns and villages. Thus, at the time of the Norman Conquest, the population of England was likely less than 1 million people and that of London was, probably, some 10,000 people or so, ${ }^{33}$

- Given this, one suspects that keeping a 'disorderly house' was not an offence developed by the courts in early times. It arose with an increase in population. Certainly, it is not mentioned in early texts on English criminal law. ${ }^{34}$

\footnotetext{
${ }^{24}$ W Sheppard, Grand Abridgment of the Common and Statute Law of England (sold by George Sawbridge et al, 1675).

${ }^{25}$ W Nelson, Abridgment of the Common Law (E \& R Gosling, 1725-6). This has been reprinted.

${ }^{26}$ M Bacon, New Abridgment of the Law (H Gwillim (ed), $5^{\text {th }}$ ed, 1798).

${ }^{27}$ E Viner, A General Abridgment of the Law and Equity (GCJ \& J Robinson, $1^{\text {st }}$ ed, 1741-57, $2^{\text {nd }}$ ed 1791). This has been reprinted by the Law Book Exchange (there is also a CD with wordsearch).

${ }^{28} \mathrm{~J}$ Comyns, Digest of the Laws of England (A Hammond, last ed, 1822). See also J Lilley, Practical Register (2 ${ }^{\text {nd }}$ edn, 1765).

${ }^{29}$ Archbold, n 15, para 20-246.

${ }^{30} R v \operatorname{Berg}(1927) 20$ Cr App R 38.

${ }^{31} R v$ Quinn and Bloom [1962] 2 QB 245.

32 Texts on Anglo-Saxon law did not refer to 'disorderly houses' although they did deal with adultery and fornication (see 5). See FL Attenborough, The Laws of the Earliest English Kings (NY, 1963); AJ Robertson, The Laws of the Kings of England from Edmund to Henry I (Cambridge UP, 1925) and B Thorpe (ed), Ancient Laws and Institutions of England (1840). Early French coutumes also did not reveal such an offence, see eg. JA Everard, Le Grand Coutumier de Normandie (Jersey and Guernsey Law Review Ltd, 2009) and FRP Akehurst, The Coutumes de Beauvasis of Philippe de Beaumanoir (Univ. of Pennsylvania Press, 1992).

${ }^{33}$ Various websites propose these figures (or similar) although there is no means of proving their exactitude. See also AH Thomas, Calendar of Plea and Memoranda Rolls 1364-1381 (Cambridge UP, 1929), p lxii (statement of Peter of Blois to Pope Innocent III in 1199 that the City of London comprised 40,000 inhabitants). A figure of 40-50,000 during the whole of the $14^{\text {th }}$ century has also been proposed. Ibid.

${ }^{34}$ See LJ Downer, Leges Henrici Primi (c. 1110)(Oxford, Clarendon Press, 1972); GDG Hall (ed), Glanvill, The Treatise on the Laws and Customs of the Realm of England (c. 1189)(Nelson, 1965); Bracton, n 7 and FM Nichols (ed), Britton (John Byrne \& Co, 1901).
} 
When did this offence first arise? One suspects that it was connected with the development of common inns (hotels) in England. Common inns should not be confused with taverns (public houses). The former provide board and lodging, as opposed to just being drinking establishments. ${ }^{35}$ Today, common inns are more usually called 'hotels' ${ }^{36}$ In respect of common inns:

- After the Norman Conquest, common inns ${ }^{37}$ would have been few and far between. Further, in early medieval times, travel was also restricted. It tended to be limited to royalty, the very wealthy and clerics as well as their retainers. Persons who, when travelling, took lodging in the houses (castles) of the rich or in monasteries; ${ }^{38}$

- With 'going on pilgramage' becoming popular in the 12th and 13th centuries the monks built separate lodgings called inns (from the Saxon 'inne', the word for room) for travellers who would, often, have paid for their board and lodging. ${ }^{39}$ From these, likely derived inns which were open to the public on a commercial basis, severed from the monastery.

In the case of London, given its rapidly increasing population after the Norman Conquest ${ }^{40}$ and its expanding trade with foreigners, it is likely that 'common' (public) inns originated from early times. ${ }^{41}$ These were carefully watched by the State since they could harbour traitors and foreign spies.

- In the City of London, the Court of Alderman usually only permitted freemen of the City and other respectable persons to run common inns. ${ }^{42}$ An 'Association of Hostelers and Haymongers' was formed before 1327 and one would suppose that 'common' innkeepers existed prior to that; ${ }^{43}$

- Thus, the London authorities wanted inns to be well regulated. As a result, it is likely that inns which permitted prostitution (or which were brothels in disguise) would have been suppressed by the courts as 'disorderly'. In this respect, it may be noted that a Bill issued by the Mayor and Alderman of London to London innkeepers on 19 December 1343 provided that: 'all hostellers were under surety not to receive evil doers. ';4

\footnotetext{
${ }^{35}$ See generally, GS McBain, Abolishing the Strict Liability of Innkeepers [2006] Journal of Business Law, October 705-55. Taverns tended to be a reference to houses that sold wine and common alehouses to houses that sold beer. However, 'tavern', at least by the $18^{\text {th }}$ century, was then used as an expression for any drinking place. See generally, S \& B Webb, The History of Liquor Licensing (rep.Frank Cass, 1963 ), p 22.

${ }^{36}$ The word 'hotel' did not come into use until c. 1770, see McBain, n 4, p 90, fn 5.

${ }^{37}$ The word 'common' derived from 'commune' (public). The City of London was granted the status of a 'commune' in 1191 and, to this day, its liverymen meet in 'common hall' and elect representatives known as 'common councilmen' who meet in 'common council'. 'Common' (ie. public) was also used in a pejorative sense such as 'common prostitute', 'common scold', 'common drunkard' etc. See generally, McBain, n 35 , pp 711-2, fns $39 \& 42$.

${ }^{38}$ McBain, n 35, pp 707-8. Monastic orders such as the Benedictines or Knights of the Order of St John of Jerusalem (also, called the 'Hospitallers', which order was dissolved in 1540) offered hospitality as part of their monastic function. Ibid, p 708. See also McBain, $n 4$, pp 90-8.

${ }^{39}$ McBain, n 35, p 708.

${ }^{40}$ It likely had a population of c 80,000 by 1300 .

${ }^{41}$ The oldest inn still existing in England is said to date from 1189 (Ye Olde Trip in Nottingham). However, there is no direct evidence of this; nor whether it was originally an inn as opposed to a tavern. That said, 1190-1200 would have been a likely time for commercial inns to develop in order to provide board and lodging for people making for Dover from all over England, to go on crusade (Richard I (1189-99) went on crusade in summer of 1190). Around 1190-1200 would also likely have been the time when monasteries became increasingly reluctant to put up general travellers. See also SS, vol 60, pp 55 \& 120 (references to persons keeping inns in 1289 and in the time of Henry III (1216-72). See also Fleta (c 1290), n 8, vol 72, pp 50-1 justices in eyre could investigate 'magnates and others who seek hospitality at houses of religion, although they have not been invited by the rulers, whether at the expense of the religious or their own, against the will of the religious' and 'those who have sent to the houses or manors of religious or others, men, horses or dogs to sojourn at other people's expense'.

${ }^{42}$ McBain, n 35, p 709. See also RR Sharpe (ed), Calendar of Letter-Books of the City of London, Letter Book C (1291-1309), p 16 'No foreigner nor stranger to keep hostel within the City, but only those who are freemen of the City, or who can produce a good character from the place whence they have come, and are ready to find sureties for good behaviour.'

${ }^{43}$ HT Riley, Memorials of London and London Life...AD 1276-1419 (Longman, 1868), p 166 (petition of 1327 of hostelers and haymongers of London and Ordinance made thereon). See also p 323 (Ordinance of 1365, re hostellers, selling horsebread) and 347-8 (Ordinance of 1371 concerning hostellers selling victuals). These references would have been to common hostlers, as would likely have been the reference, in 1320 , to 'John le Hosteler', see RR Sharpe (ed), Calendar of Letter-Books of the City of London, Letter Book E (1314-1337), p 120. See also HT Riley, Munimenta Gildhallae Londoniensis, Liber Albus, Liber Custumarum et Liber Horn, vol 1 (Longman, 1859), Liber Albus (composed 1419), vol 1, pp lv-lviii (hostelers and lodging house keepers). The Liber Albus was translated by HT Riley, Liber Albus: The White Book of the City of London (Richard Griffin \& Co, 1861)(I shall refer to it as the 'White Book', as opposed to the untranslated Liber Albus). The earliest reference to a 'common hostler (hosteler)' I have yet found is in a charter of Edward II (1307-27) of 8 June 1319 to the City of London, see White Book, p 128.

${ }^{44}$ AH Thomas (ed), Calendar of the Select Pleas and Memoranda of the City of London 1323-1364 (Cambridge UP, 1926), p 156. See also SE
} Thorne (ed) Year Books of Richard II 8-10 Richard II 1385-1387 (Ames Foundation, 1987), pp 145-6. It refers to Thomas v Sampson (1384) in 
- In Anglo-Saxon times, London had its own portreeve (later, replaced by a mayor) as well as a court of hustings. ${ }^{45}$ Further, a charter of Henry I (1100-35) c. 1132 granted the citizens of London a lease of the City of London and Middlesex as well as the right to appoint sheriffs for both. ${ }^{46}$ The court of hustings and the sheriffs' court, ${ }^{47}$ therefore, were able to regulate what, today, would be called local government matters, such as brothels and common inns. ${ }^{48}$

In conclusion, in medieval times, it seems likely that the concept of 'disorderly house'would have been connected with the establishment - and increase - of common inns (hotels). Also, with brothels, which are now considered.

\section{Keeping a Disorderly House: The Medieval Position - Brothels}

Brothels existed in London in Roman times. Doubtless, they continued in Anglo-Saxon times - albeit London was often deserted, or devastated by fire, after the Romans quit Britain in AD $410 .{ }^{49}$ In medieval times, brothels were known by the word 'stews', an anglicisation of the Anglo-Norman, estuis. ${ }^{50}$

- Coke alleged that there was no word for a brothel in the English language. ${ }^{51}$ However, this is only partly true, since the word 'estui' (stew), itself, is the French translation of a reference to Roman public baths (balneum) in which sexual activity (paid and unpaid) often took place. ${ }^{52}$ Such bath-houses also existed in medieval England and some provided lodging as well as a bath; 53

- Further, regardless of brothels, prostitutes were a problem in early medieval times in London. Thus, the legal text, Fleta (c. 1290), noted that it was the duty of the King's marshall (a grand sarjeanty granted in fee to the Duke of Norfolk) to protect the 'verge' of the king's palace. This included keeping it free from prostitutes (meretricibus communibus). ${ }^{54}$

which Belknap CJ stated (translation) 'Certes [ie. Certain it is], the case of a common hosteller differs from that of another furnisher of lodgings, for a common hosteller is his trade and he is bound to accept everyone in his hostel in spite of his preference, unless he be notoriously or obviously of bad repute, but another is not bound to do so: just as a common taverner is obliged to hold his tavern common to all, so must a hosteller for his common hostel.' (italics supplied).

${ }^{45}$ GS McBain, Liberties and Customs of the City of London - Are there any Left? (2013) Int. Law Research, vol 2, no 1, 32-95, fns 41 \& 42. The portreeve (portgrave) was the ruler (or chief officer) of a town or borough. After the Norman Conquest, the portreeve was often identified with the mayor or one holding an equivalent position. The Anglo-Saxon word 'husting' signified a general council or court.

${ }^{46}$ Ibid, $\mathrm{p} 6$.

${ }^{47}$ There were two sheriffs' courts in the City of London, but they were treated as one. See McBain, n 45, p 11.

${ }^{48}$ Ibid, pp 6, 10-1.

${ }^{49}$ For example, in AD 457, Britons evacuated London after being attacked by Anglo-Saxons who took control. In AD 842 Norsemen seized and destroyed London, massacring the inhabitants. In December 1066, Duke William (later William I (1066-87) laid waste to Southwark.

See D Brandon \& A Brooke: Bankside: London's Original District of Sin (2013), pp 18-9. Also, D Whitelock (ed), The Anglo-Saxon Chronicle (Eyre \& Spottiswoode). The City of London was encircled by a wall built by the Romans c. 200-220.

${ }^{50}$ See Anglo-Norman dictionary, anglo.norman.net, 'Estuve' (other variant spellings) 'vapour bath... hothouse...stewhouse'.

${ }^{51}$ Coke, n 10, vol 3, p 205 'The word estuis or stewes is French, we having no English word for it'. See Oxford English Dictionary ('OED') (definition of brothel) for the late development of the word. 'Brothel' (a fore-shortening of the words 'brothel's house' or 'brothel house') originally referred to the person, with 'bordel' (anglicisation of the Spanish 'bordello') referring to the place. A brothel was also known as a 'bawdy house' or 'house of ill fame'. RM Karras, Common Women: Prostitution and Sexuality in Medieval England (1996), p 37 'The bankside area in the Winchester liberty was known as 'Les Stuwes' by the middle of the fourteenth century...'.

52 J Cowell, A Law Dictionary or the Interpreter (London, 1708) (stewes) 'Are those places which were permitted in England to women of professed incontinency, and that for hire would prostitute their bodies to all commers. It is derived from the French estuves, 1. therma, vel balneum, because dissolute persons are wont to prepare themselves for venerous acts by bathing.' (it may be noted that Cowell provided no definition of 'disorderly house'). OED, n 51, (definition of stew) ' 3 . A heated room used for hot air or vapour baths: hence a hot bath. 4 A brothel (developed from sense 3), on account of the frequent use of the public hot-air bath-houses for immoral purposes.' See also Riley, $\mathrm{n} 43$, p 648 (in a fn he noted: 'stew' or 'stove' being the equivalent of the Latin fornix, an arched place, artificially heated; such places or bagnios, being especially frequented by vicious persons of both sexes in ancient Rome'). The latin for brothel was 'fornix', that for stove or oven, 'fornax.' See CT Lewis, A Latin Dictionary (Oxford, Clarendon Press, 1879). See also Burford, Bawds and Lodgings: A History of the London Bankside Brothels c 100-1675 (Peter Owen, 1976), pp 22 \& 61.

${ }_{53}$ PE Jones (ed), Calendar of the Plea and Memoranda Rolls (1437-1457)(Cambridge UP, 1954), p 88 (1439), p 17 (1439) 'Bond of Magdalen Johnson and William Wolnore, skinner, in $£ 10$ to the chamberlain that she would keep a respectable stewhouse (balneum) and not allow any prostitution, adultery or fornication to take place there.' AH Thomas, (ed), Calendar of the Plea and Memoranda Rolls (1413-1437)(Cambridge UP, 1953), p 154 (ward of Crepulgate Without, a London ward) 'They also indict the stew-house in the ward as a nuisance and trouble to the neighbours, because it is a common house of harlotry and bawdry, and a great resort of thieves and also of priests and their concubines, to the great disgrace of the city and the danger and mischief of the neighbours and passers-by...'

${ }^{54}$ Fleta, n 8, p 114. Coke, n 10, vol 3, p 205 also cited 7 Edw 3 (1333) fo 23-4 9 which appears to be a reference to 7 Edw 3 pl 1 fo $23 \mathrm{~b}-24 \mathrm{a}$ (1333), see Seipp Index 1333.066 (woman who fled king's household). Translations of many of the 22,000 cases in the Yearbooks have been published online by professor David Seipp in the form of an Index, www.bu.edu/law/faculty/scholarship/yearbooks). See also The Case of the Marshalsea (1612) 10 Co Rep 68b (77 ER 1027) at 77a. 


\section{(a) Brothels in Britain - Early History}

The problems of brothels in London - and their suppression as common (public) nuisances - occurred many times throughout London's history. ${ }^{55}$ A description of the Roman and Anglo-Saxon period is useful to understanding later developments.

- In Roman times, soldiers were not permitted to marry until the $2^{\text {nd }}$ century AD. Thus, camp followers (prostitutes) were inevitable. In Roman Britain, Southwark was a military base and there were also brothels in this area; ${ }^{56}$

- The system for licensing prostitutes in Roman Britain was likely no different to that employed in Rome. Women wishing to become prostitutes (meretrices) were licensed by a public official, the Aedile. After being registered on a roll the prostitute received a 'licentia stupro. ${ }^{57}$ This gave her a legal right to her fee so that she could sue for the same;

- The Roman State had a vested interest in prostitution, since it collected taxes from prostitutes.

Probably, brothels continued for some time after the Romans left Britain in AD 410. However, under the influence of Christianity in the later Anglo-Saxon period, prostitution was suppressed. ${ }^{58}$ Also, adultery ${ }^{59}$ and fornication were punished ${ }^{60}$ and clerical celibacy enforced. ${ }^{61}$ That said, one suspects that some brothels, especially in London, remained officially (or unofficially) permitted.

\section{(b) London Brothels - Ordinance of 1161: Southwark}

It is unclear what the position re prostitution was after the Norman Conquest of 1066. However, when Duke William (later, William I, 1066-87) made to attack London he destroyed Southwark. ${ }^{62}$ Presumably, the brothels there were also destroyed. From Domesday Book 1086, it seems clear that Southwark was part of Crown land. ${ }^{63}$

- It also seems that - in 1107- the Abbot of the Priory of Bermondsy granted to the Bishop of Winchester a stretch of land along the waterside, extending to the end of Bankside, at a rent of $£ 8$ a year. As lord of the manor, the latter was responsible for administering ecclesiastical correction there to the 'light-tayled huswives of the bank (bankside)' as a result of their forrnication (harlotry) ('cifeshad'); ${ }^{64}$

- The next concrete data is an Ordinance of Henry II (1154-89) of 1161. Bearing the title 'Ordinances touching the Government of the Stewholders in Southwark under the Direction of the Bishop of Winchester' (spelling modernized), it established 18 brothels (stewhouses) on Crown land in Southwark, to be regulated by the Bishop of Winchester. ${ }^{65}$ The bailiffs and constables of Southwark were responsible for a weekly inspection of these brothels and the enforcement of the Ordinance, ${ }^{66}$

\footnotetext{
${ }^{55}$ For interesting general texts see Karras, n 51, Brandon, n 49; Burford, n 52 and MA Laughran, The Bankside Stews: Prostitution in London 1161-1546 (thesis of April 1989 submitted in partial fulfilment of the requirements for a BA in History from the College of William and Mary, Virginia, USA, available online).

${ }^{56}$ Brandon, n 49, p 15 'Southwark may have been the earliest occupied part of Roman London in the sense that there was a substantial military encampment there defending the new crossing before much of the town on the other side had been built.' It has been asserted that 'Southwark' derives from 'Sudwerka' (Southwork), to reflect such fortifications which included a bridge built pre AD 50. Ibid, pp 8 \& 15.

${ }^{57}$ 'Stuprum' was the latin for 'defilement, dishonor, disgrace.' See Lewis, n 52. See also Burford, n 52, p 18. For prostitution under Roman law see OF Robinson, The Criminal Law of Ancient Rome (John Hopkins University Press, 1995), ch 5.

${ }^{58}$ Attenborough, n 32, p 11, Decree of Edward the Elder (975-78) and king Guthrum (Danish king of East Anglia, died 890) 'If...notorious prostitutes be met with anywhere in the country, they shall be driven from the land and the nation shall be purified'. See also Robertson, $\mathrm{n} 32$, p 93, Laws of Aethelred (978-1016) which made similar provision.

${ }^{59}$ Ibid, p 71, Laws of king Alfred the Great (871-99) (concerning adultery with the wives of nobles and commoners), 'If anyone lies with the wife of a man whose wergild is 1200 shillings etc'.

${ }^{60}$ Ibid, Laws of Athelbert (king of Kent, 858-60), p 5 'If a man lies with a maiden belonging to the king etc..'

${ }^{61}$ Ibid, p 103, Decree of Edward the Elder (975-78) and King Guthrum (Danish king of East Anglia), 'if a man in orders...commits...adultery, he shall pay either wergild or fine or lahslit, according to the nature of the offence; and in any case shall he make compensation to God as the canon directs; and he shall find surety for the compensation or go to prison.' 'Lahslitt' was a fine for a breach of the (Danish) law, see JRC Hall, A Concise Anglo-Saxon Dictionary (Cambridge UP, $4^{\text {th }}$ ed, 1975).

${ }^{62}$ See $\mathrm{n} 49$.

${ }^{63}$ Burford, n 52, p 37 'there were sixteen messuages on the Bankside which brought the Crown eighteen shillings and twopence a year.' He also noted that Edward the Confessor (1042-66) owned large tracts of land in Southwark and a number of properties on the Bankside.

${ }^{64}$ Ibid, pp 37-8. 'Cifeshad' meant fornication. 'Cifes' was a 'concubine' or 'harlot'. See Hall, n 61.

${ }^{65}$ For the text of the Ordinance of 1161, see Burford, n 52, pp 44-50. Also, Laughran, n 55.

${ }^{66}$ J Stow, Survey of London (first pub 1598, see rep Dent \& Sons, 1965), p 360 'In a parliament holden at Westminster, the $8^{\text {th }}$ of Henry II [1154-89], it was ordained by the commons, and confirmed by the king and the lords, that divers constitutions for ever should be kept within
} 
- The real purpose of this regulation was to secure money for the Crown from the ground rents paid from the brothels. Also, from fines arising from the infraction of the Ordinance. ${ }^{67}$ It seems that these brothels were not treated as such, but as boarding houses. ${ }^{68}$ This may explain the expression 'disorderly house' or 'bawdy house', and, thus, the absence of a specific word for a brothel, which Coke was later to note, ${ }^{69}$

- To separate prostitutes in Southwark from respectable women in visual terms, the former were prohibited by the Ordinance of 1161 from wearing an apron. ${ }^{70}$ Various other clothing restrictions were later imposed, such as a rayed hood.

\section{(c) Brothels in London - City of London: 1161-1381}

Despite the restriction to Southwark it is likely that brothels continued in the City. At least, unofficially. Over the centuries there were many attempts by the London authorities to regulate (or suppress) brothels in London - both in Southwark and the City. However, much depended on the moral condition of the times as well as whether the Crown derived revenue from such activities. Thus:

- As well as the 18 brothels in Southwark, in 1240, a street outside Newgate and the City walls was designated ('Cock Lane'). ${ }^{71}$ The names of other London streets suggest the likely presence of brothels there at one time or another; ${ }^{72}$

- In 1276, in the Assizes of the City of London read by the mayor and reputable men, it was ordered that prostitutes could not live within the walls of the City. ${ }^{73}$ This, likely, had the effect of moving most of them to the brothels in Southwark and Cock Lane ${ }^{74}$

- In 1285, the prohibition on prostitutes in the City was re-stated. Punishment for such women being found within the walls of the City was 40 days in prison. Also, 'let their limits [Cock Lane] be assigned unto them, ${ }^{75}$

- In 1327, Edward III (1327-77) granted the City of London some jurisdiction over Southwark, 'for the confirmation of our peace within the city, bridling the wickedness of...malefactors'. ${ }^{76}$ The Ordinance of 1161 was re-issued; ${ }^{77}$

- In 1347, Edward III ordered the suppression of a brothel in Water Lane ${ }^{78}$ so that the Carmelite friars (the Brethren of the Order of St Mary of Mount Carmel, also called the White Friars) who had a monastery in Fleet Street, were left undisturbed; ${ }^{79}$

that lordship or franchise, according to the old customs that had been there used time out of mind: amongst the which these following were some, viz. That no stewholder or his wife should let or stay any single woman, to go and come freely at all times when they listed...[Stow then cites other provisions of the Ordinance of 1161] .'

${ }^{67}$ Laughran, n 55, pp 12, 14. On the continent a tax on prostitutes ('putage') was sometimes levied, Ibid, p 12.

${ }^{68}$ Ibid, $\mathrm{p} 17$.

${ }^{69}$ See $\mathrm{n} 51$

${ }^{70}$ Ordinance of 1161, item 35. See Burford, n 52, p 49.

${ }^{71}$ Cock Lane is a small street in EC1. It was originally called 'Cokkes Lane' (Cocks Lane). See also Stow, n 66, p 332, 339.

72 Ibid, pp 23, 44. For example, 'Cock Lane' (the name originates from the early 1200's), 'Bathestrares Lane' (in use by 1246), 'Stew Lane' (near the present Upper Thames Street), 'Bordhaw Lane', 'Gropec....lane' (near present St Mary Colechurch in Cheap), 'Love Lane' (first recorded in 1336). Laughran notes that other towns such as Oxford, Petersborough, Bristol, Worchester, York etc had streets with similar names. The Ordinance of 1161 relating to Southwark (see n 65) may have governed the Cock Lane brothels. Ibid, p 24. It appears that the port towns of Sandwich (in Kent) and Southampton (in Hampshire) also had authorized brothels, but at a much later date. See also Karras, n 51, pp 35-7 and Burford, n 52, p 67.

${ }^{73}$ See RR Sharpe, Calendar of Letter Books of the City of London, Letter Book A 1275-1298, p 218 'that no whore of a brothel be resident within the walls of the City.' (Assize of Gregory de Rokesle, mayor, AD 1276-8). This Assize was also cited in AH Thomas (ed), Calendar of Early Mayor's Courts Rolls 1298-1307 (Cambridge UP, 1924), p 211. See also Liber Albus, n 43, vol 1, p 275.

${ }^{74}$ See Riley (Munimenta), n 43, p liii. See also pp xlix \& 277 (ordered that no waterman should convey a man, or woman, in their boats to the stews in Southwark, except during the day). See also Calendar of Letter-Books of the City of London, Letter-Book H 1375-1399, p 372 (1391), pp 371-2 and White Book, n 43, p 242.

${ }^{75}$ White Book, n 43, pp 246-7 'no common woman shall dwell within the walls of the City. And if any such shall hereafter be found within the City residing and dwelling, she shall be imprisoned forty days'. See also Laughran, n 55, pp 33-4 and Burford, n 52, p 69. See also Articles of the Wardmotes (c Edward II (1307-27), p 287 'no woman of lewd life, bawd, courtesan, or common scold, be resident in the ward; but be forthwith removed by the alderman and driven out of the ward, or else be brought by the constables and bedel unto the compter, there to remain in manner provided in the Article as to the Peace.' See also p 291 (inquisitions at the wardmotes, re woman of lewd life etc).

${ }^{76}$ See McBain, n 45, pp 29-30. A charter of 1462 confirmed this grant (as well as accorded various franchises in Southwark to the City) and a charter of 1550 granted the manor of Southwark to the City. Ibid. p 50. For a map of the manors in Southwark in 1550, see Brandon, n $49, \mathrm{p} 184$.

${ }^{77}$ Laughran, n 55, p 47. 
- In 1351 (and in 1382), by proclamation, women of 'bad repute' were restricted to a certain garb, notably, a rayed (that is, a striped) hood; ${ }^{80}$

- In 1381, during the Peasant's Revolt, a London brothel was destroyed by the peasants and, in 1382, ordinances were made by the mayor and aldermen of the City of London for the punishment of bawds, harlots, unchaste priests and the like. ${ }^{81}$

\section{(d) London Brothels - City of London: 1381-1655}

- In 1390, it was enacted that no brothels should be kept in Southwark but in the common places appointed; ${ }^{82}$

- In 1393, a proclamation provided that prostitutes could only live in the stews in Southwark or in Cock Lane; ${ }^{83}$

- In 1417, an Ordinance provided for the abolition of brothels in the City as well as imposed restrictions on bathouses (stews) in the City and the suburbs; ${ }^{84}$

- In 1483, Edward V (1483) issued a proclamation against prostitutes wandering around the City; ${ }^{85}$

- In 1506, the 18 brothels in Southwark were ordered closed. However, 12 were later permitted to operate again; ${ }^{86}$

${ }^{78}$ This street is in EC3, not far from the Tower of London.

${ }^{79}$ Coke, n 10, vol, 3, p 205. Coke cited 21 Edw 3 (1347) pt $1 \mathrm{~m} 6$ (Calendar of Close Rolls) and stated 'The record saith, Rex praecipit majori civitatis London quod amoveri faciat omnes mulieres meretrices in venella prope fratres Camelitarium in Fletestreet inhabitantes.' ('The king instructed the mayor of the City of London to ensure the removal of all the women prostitutes living in a lane near the monastery of the Carmelite friars in Fleetstreet').

${ }^{80}$ Riley n 43, p 267 (proclamation of 1351 as to the dress of common women). Ibid, p 458 (women of bad repute were restricted to a certain garb, 1382). A similar proclamation seems to have been made earlier, in the time of Edward I (1272-1307), see Riley, (Munimenta) n 43, p lii. These sumptuary laws against prostitutes (so that they could not be mistaken for respectable women) had also applied in Roman times (Roman women prostitutes had to wear a toga, could not wear jewellery etc). See also Laughran, n 55, p 48-9; Letter Book A (see n 73), p 220 and RR Sharpe, Calendar of Letter-Books of the City of London, Letter Book F 1337-1352, p 241 (proclamation of 1351). See also Karras, n 51, pp 21-2 and Burford, n 52, p 73.

${ }^{81}$ The brothel was located in Southwark and occupied by Flemish women. See RB Dobson, The Peasants' Revolt of 1381 (Macmillan, 1970), pp 156, 162 \& 175; GS McBain, Abolishing the Crime of Treason (2007) 81 Australian LJ, p 7, n 65 and A Dunn, The Peasants' Revolt (Tempus Publishing Ltd, 2004), p 113. Riley (Munimenta), n 43, p lii 'From the Letter-Books we gather that in the middle of the $14^{\text {th }}$ century most of these women [prostitutes in London] were Flemings by birth.' Laughran, n 55, p 45 notes that many Flemish women came to England in the $14^{\text {th }}$ century as a result of Flemish weavers being invited here by Edward III (1327-77). When such women were unable to work, many drifted into prostitution. It was said that Englishwomen disdained to act as prostitutes, Stow, n 66, p 361. See also Karras, n 51, pp 56-7. For the 1382 ordinances see Letter Book H, n 74, p 189 (see p xxi, for the 1381 destruction of the brothel in Southwark). Also, Riley, Liber Albus, n 43, vol 1, pp 457-60.

${ }^{82}$ Coke, n 10, vol 3, p 205. Coke cited RP 14 Ric 2 (1390) nu 32 for which see The Parliament Rolls of Medieval England (Scholarly Digital Editions, which is also on CD)('RP'), iii 282, item 32 'the commons of the borough of Southwark request that no stews be kept in the borough of Southwark, except in the common places maintained for this. Answer. The king wills it.' See also Burford, n 52, p 79 (ordinance re nightwalkers and women of ill repute).

${ }^{83}$ Riley, n 43, pp 534-5 (regulation of 1393 as to street walkers by night, and women of bad repute) 'whereas many and divers affrays, broils, and dissensions, have arisen in times past, and many men have been slain and murdered, by reason of the frequent resort of, and consorting with, common harlots, at taverns, brewhouses of huksters, and other places of ill-fame, within the said city, and the suburbs thereof; and more especially through Flemish women, who profess and follow such shameful and dolorous life: - we do by our command forbid, on behalf of our lord the king, and the mayor and aldermen of the city of London, that any such women shall go about or lodge in the said city, or in the suburbs thereof, by night or by day; but they are to keep themselves to the places thereunto assigned, that is to say, the Stews [lestuphes: they were situated on Bankside, Southwark] on the other side of the Thames, and Cokkeslane [Cock Lane, near Smithfield, City of London, EC1]; on pain of losing and forfeiting the upper garment that she shall be wearing, together with her hood, every time that every one of them shall be found doing to the contrary of this proclamation.' See also Letter Book H, n 74, p 4021. Southwark was a notorious place for malefactors, see McBain, n 45 , p 29 and n 76.

${ }^{84}$ Riley, n 43, p 647 (Ordinance made for the abolition of stews within the City) 'no man or woman in the City of London, or in the suburbs thereof, should from thenceforth keep any stews within the City of London, or in the suburbs thereof for lodging therein any men or women by day or by night'). See also Laughran, n 55, p 62 and RR Sharpe, Calendar of Letter-Books of the City of London, Letter-Book I 1400-1422 (1909), pp xix-I \& 119-2. See also RR Sharpe, Calendar of Letter Books of the City of London, Letter Book K (Henry VI,1422-71)(1911), pp 230-1. For bans on brothels in York and other cities see Karras, n 51, pp 18-20. See also Burford, n 52, p 90.

${ }^{85}$ Laughran, n 55, pp 70-1. See also Burford, n 52, p 107.

${ }^{86}$ Stow, n 66, p 361 'Robert Fabian writeth, that in the year 1506...the said stew-houses in Southwarke were for a season inhibited, and the doors closed up, but it was not long (saieth he) ere the houses there were set open again, so many as were permitted, for (as it is said) whereas before were eighteen houses, from thenceforth were appointed to be used but twelve only. These allowed stew-houses had signs on their fronts, towards the Thames, not hanged out, but painted on the walls, as a Boar's head, the Cross keys, the Gun, the Castle, the Crane, the Cardinal's hat, the Bell, the Swan etc.' Robert Fabian (Fabyan, died 1513) was a London draper, sheriff and alderman of the City of London and author of 
- In 1513, Henry VIII (1509-47) issued a proclamation forbidding brothel keeping in the army and inflicting branding on army prostitutes, ${ }^{87}$

- In 1546 , by proclamation (with a herald and trumpet) all brothels in Southwark were suppressed. ${ }^{88}$ However, this did not extirpate prostitution and they were re-established by the time of Elizabeth I (1558-1603); ${ }^{89}$

- In 1655 , brothels were again suppressed. ${ }^{90}$

Coke (published in 1641) noted that:

Before the reign of Henry 7 [1485-1509] there were eighteen of these infamous houses, and Hen[ry] 7 for a time forbad them: but afterwards twelve only were permitted, and had signs painted on their walls: as a Boar's Head, the Cross Keys, the Gun, the Castle, the Crane, the Cardinal's Hat, the Bell, the Swan etc. ${ }^{91}$

Coke also noted:

And the keeper, he or she, of such houses is punishable by indictment at the common law by fine and imprisonment: for although adultery and fornication be punishable by the ecclesiastical law, yet the keeping of a house of bawdry or stews, or brothel-house, being as it were a common nuisance, is punishable by the common law, and is the cause of many mischiefs, not only to the overthrow of the bodies and wasting of their livelihoods, but to the endangering of their souls. ${ }^{92}$

As to the punishment for prostitutes in the City of London: ${ }^{93}$

- Carting Prostitutes. It was said that a woman found to be a whore ${ }^{94}$ at a wardmote inquest could be carted and whipped through the streets of London. However, this was doubted by Lord Mansfield, in 1783, on the basis that such a custom had not been proved; ${ }^{95}$

- Parading Prostitutes. The White Book of the City of London (1419) provided that a common courtesan (prostitute) was to be taken from prison to Aldgate with a hood of striped cloth and a white wand in her hand. From there, with musicians, she was to be taken to the thew (a form of pillory). And, from the thew, she was to be taken Cheapside and Newgate to Cock Lane to take up her abode. For a second offence she

two chronicles. See Oxford Dictionary of National Biography ('ODNB'). Also, H Ellis (ed), The New Chronicle of England and France in Two Parts by Robert Fabyan (London FC \& J Rivington, 1811) and AH Thomas \& ID Thornley, The Great Chronicle of London (1938, reprinted 1983). See also Burford, n 52, p 114. Also, CL Kingsford, Chronicles of London (Oxford, Clarendon Press, 1905).

${ }^{87}$ See Burford, n 52, 120 (proclamation forbidding Brothel Keeping in the Host). See also Laughran, n 55, p 75. For an attempt at suppression in 1535, see Burford, n 52, p 122.

${ }^{88}$ Coke, n 10, vol 3, pp 204-5 'King H 8 suppressed all the stewes or brothel-houses, which had long continued on the Bankside in Southwark, for that they were (as had been said) prohibited by the law of God, and by the law of the land. And those infamous women were not buried in Christian burial when they were dead, nor permitted to receive the rites of the church whilst they lived.' (spelling modernized). Coke cited Stow, see $\mathrm{n}$ 66, at $\mathrm{p}$ 362. For the proclamation of 13 April 1546, see PL Hughes \& JF Larkin, Tudor Royal Proclamations (Yale UP, 1969), vol 1, p 365. See also Case of Proclamations (1611) 12 Co Rep (77 ER 1352 ) and GS McBain, Expanding Democracy - Transferring the Crown Prerogative to Parliament (2014) Rev. of European Studies, vol 6, no 1, p 39, n 299. See also Burford, n 52, p 125.

${ }^{89}$ It seems that prostitutes turned to working in common taverns (which had private rooms). See also Brandon, $\mathrm{n} 49, \mathrm{p} 125$ et seq and Karras, $\mathrm{n}$ 51, pp 71-2. For the instruction of the Star Chamber - where cottages had been built in London contrary to a proclamation of 7 July 1580 , and they were 'brothelle howses' - that they should be burnt and those which were beautiful and spacious edifices should be converted into garners and storehouses for grain and other merchandise, see J Hawarde, Les Reportes del Cases in Camera Stellata 1593-1609 (ed Baildon, rep Law Book Exchange, 2008), pp 79-80. For one indicted in 1534 in Middlesex for keeping a bawdy house ('bordelhouse') see The Reports of Sir John Spelman, SS 93, vol 1, p 100. See also The Notebook of Sir John Port, SS 102, pp 64-5 citing $R v$ Betyn (1529) (woman indicted that she was a whore commonly who kept a disorderly house; garda meason [communement] de male governance). Indictment said that she and another woman were 'common whores [and] scolds, of a suspicious mode of living, keeping bawdery in their houses to the nuisance of their neighbours living nearby and as a bad example to all other such delinquents, and against the peace of the aforesaid lord king.'

${ }^{90}$ T Fuller, Church History of Britain (1655), vol 5, p 239 'At this time also, by the king's command, were the stewes suppressed.'

${ }^{91}$ Coke, n 10, vol 3, p 205 (quoting Stow, see n 86).

92 Ibid, p 204. Coke cited 11 Hen 6 c 1(1433) (no person dwelling in the stews may be a juror or keep a tavern), see RP, n 82, iv 447a.

93 This seems to have been a London custom only.

${ }^{94}$ Other words employed to describe a prostitute were 'bawd', 'harlot', 'strumpet' and 'meretrix'. It may be noted that: (a) 'bawd' originally referred, in most instances, to the male procurer or pander and only after c. 1700 did it refer to a procuress or a woman brothel keeper; (b) ' harlot' in the $13^{\text {th }}$ century referred to men (to rogues and vagabonds etc) and only from the $15^{\text {th }}$ century did it refer to a prostitute as well as to a female juggler, dancing girl, ballet dancer or actress (all of which professions were often linked to prostitution and were, sometimes, euphemisms for a prostitute). See generally OED, n 51, (definitions of these words). The word 'whore' was Anglo-Saxon 'hore').

${ }_{95}$ See McBain, n 45, p 48. Also, Stainton and his Wife v Jones (1783) 1 Douglas Reports 380 at n 96 (99 ER 245). Cf. Brandon, n 49, p 88 asserts that the wife of the Elizabethan actor, Edward Alleyn (1566-1626), was drawn through the streets of Sothwark in 1593 for being a prostitute. For the pillory, having their head shaved and other signs of public shame etc for prostitution, see Karras, n 51, p 15. 
was to be put in the thew for a certain time at the discretion of the mayor and the aldermen of the City of London. For a third offence her hair was to be cut around her head while on the thew and 'after that, let her be taken to one of the City Gates, and let her [there] forswear the City for ever. ${ }^{96}$

- Frequenting Brothels. It was said that a police constable of the City of London - on receiving an information that a man in his ward might be frequenting a brothel with lewd women (prostitutes) - might enter it and arrest the offender for a breach of the peace without a warrant, providing the man was in such company. $^{97}$

\section{(e) Punishment of Brothel Keepers etc}

As well as the authorities (periodically) suppressing the 'recognised' brothels in Southwark (and Cock Lane) by proclamation and ordinance, in medieval times, persons who maintained brothels in their houses ${ }^{98}$ - as well as prostitutes and the procurers of prostitutes - were punished. ${ }^{99}$ There are many instances cited in the six published texts of the Calendar of Plea and Memoranda Rolls (1458-1482). For example:

- $\quad 1339$. At a congregation of the mayor and sheriffs of London on $10^{\text {th }}$ July 1339 , a presentment of jurors of the ward of Farringdon Without indicted one Thomas, son of Simon Nicol, inter alia, for 'being...a harbourer of women of ill fame.' Also, 'several other persons, male and female, for keeping disorderly houses, receiving armed nightwalkers and committing assaults '; 100

- 1430. At an inquest taken before the mayor and sheriffs of London on 1 July 1340, a jury asserted, in respect of the ward of Cripplegate Without, that 'John de Catton keeps a common bawdy house, and that John le Clerk is a receiver of bawds. ${ }^{, 101}$

The reference to a 'nightwalker' (noctivagus) ${ }^{102}$ was to those who 'walk in the night, and sleep in the day or which do haunt any house, where is suspicion of bawdry' as Lambard put it. ${ }^{103}$ He cited a case of $1497{ }^{104}$ which

\footnotetext{
${ }^{96}$ White Book, n 43, p 395. See also Kingsford, n 86, pp 146, 200, 205

${ }^{97}$ Ibid, p 47. See also G Jacob, City Liberties (printed by E \& R Nutt \& R Gosling, 1732), p 44. G Jacob, The Compleat Parish Officer (printed E Nutt \& R Gosling, 1720), p 13 'A constable having information that persons resort to a common bawdy house, and there keep company with lewd women, may, with others call'd to his assistance, enter such house, and arrest offenders for a breach of the peace. But he must find them in company with lewd women; and he is to carry them before a justice of peace, which he may do without warrant.'

${ }^{98}$ eg. Thomas, n 53, p 131 'Guyse Pawnser and Willyman his wife are common bawds and keep a stew [brothel] in their house'. At p 134 'John Balynden keeps open house within the ward notwithstanding that he is a foreigner, and he is also a maintainer of bawdry and his wife is a common bawd and brawler (contendresse).' At p 154 'They indict Gerard Clayson and his wife, occupiers of the Estwehous [stewhouse] in Grub Street, as evildoers and receivers and maintainers of harlotry and bawdry and of an evil covin who are of horrible life, and of strumpets and other malefactors, to the great nuisance and peril of neighbours and passers-by.' At $\mathrm{p} 157$ 'They present and indict White the carpenter and his wife for being as common bawds as any in London and for being receivers of strumpets...'

${ }_{99}$ As noted in $\mathrm{n} 94$, 'bawd', in early times, to the male panderer or procurer. For the punishment see White Book, n 43, pp 394-5.

100 Thomas, n 44, p 109.

${ }^{101}$ Ibid, p 124. See also pp 125-6 (in 1340) '[a] house in Apcherche Lane ... and a brewhouse near the Church of St Mary Wolnoth are the resort of bad characters; they further say that John le Parker is a receiver of evildoers and women of ill-fame...that Sarra le Mareschal, dwelling in the rents of the Archdeacon of Colchester, keeps a disorderly house.' At p 167 (in 1338) 'William de Dalton...was attached to answer a charge... of keeping a house of ill-fame to which married women and their paramours and other bad characters resorted. He was found guilty by a jury and committed to prison. After being in Newgate over two months he was released on mainprise.' At pp 188-9 (1338) 'Ellen de Evesham...keeps a disorderly house and harbours thieves and prostitutes...that [various people] keep common disorderly houses and harbor prostitutes and men of ill fame... [also] two sisters, Agnes and Juliana, living in the rents of Roger Chauntecler in Holbourne [Holborn] as prostitutes and harbourers of men of ill fame, Agnes, widow of Robert atte Hole, for letting a house to a woman of bad character, whose associates were dangerous persons; and [various others] living next to John le Bokbyndere's [Bookbinder's] house, as guilty of similar offences, and as being a source of danger to the neighbourhood.' At p 173 '(in 1338) 'Robert de Stratford...was attached to answer a charge of harbouring... prostitutes... He was found guilty by a jury, damages being taxed at $6 \mathrm{~s} 8 \mathrm{~d}$ [a fine payable for infractions of the Ordinance of 1161] , and was mainprised to come up for judgment.'

102 'Nightwalker' was a euphemism for those suspected of criminal activity at night. In particular, prostitutes, panders and those suspected of visiting prostitutes. OED , n 51 'One who walks about by night, esp. with criminal intentions; a bully or thief... a street-walker, a prostitute.' See eg Thomas, 107 (1371), pp 139-40 (nightwalker accosting women).

${ }^{103}$ W Lambard, Dueties of Constables, Borsholders, Tything-men and such other lowe and lay Ministers of the Peace $\left(1^{\mathrm{st}} \mathrm{ed} 1582,8^{\text {th }}\right.$ ed 1599)( I cite the 1599 edition), pp 11-2, referred to the right of a constable to call for assistance in the case of suspected bawdry. He stated: 'But now, for the better preventing that nothing be done against the peace, any of these officers aforesaid may take (or arrest) suspected persons which walk in the night, and sleep in the day or which do haunt any house, where is suspicion of bawdry: and they may carry them before a justice of the peace, to find sureties of their good behaviour. And if any such officer be not of sufficient strength to do that alone then he may take meet aid of his neighbours thereto: and they, in such cases, be compellable to help and assist him'.

${ }^{104} 13 \mathrm{Hen} 7 \mathrm{pl} 10$ fo 10b (1497), Seipp Index, n 54, no 1497.021. Seipp records 'all the justices. It is permitted (congeable) for every constable to take the suspected persons, who go about in the night (vont en la nuit, night walkers), and sleep in the day, or who keep suspicious company,
} 
confirmed that constables could ask others for assistance - to seize nightwalkers and bring them before a JP, to provide surety for their good behaviour. Hue and cry could also be raised against fleeing nightwalkers. ${ }^{105}$ In the Calendar of Letter Books of the City of London there are many references to keepers of bawdy houses, prostitutes, nightwalkers etc. ${ }^{106}$ Further, Thomas - who edited some of the Rolls of the Mayor's court of the City of London stated, as to the early $13^{\text {th }}$ century:

On 23 Dec 1298, for instance, a number of persons were brought before the Mayor's Court for riotous conduct and for keeping disorderly houses ${ }^{107}$...Similar offences were dealt with in 1300 and $1304 \ldots$ In 1338 the return of the ward of Farringdon Without is preserved with the mayoral precept summoning the wardmotes for Sunday after Lady Day. The midsummer wardmote of this ward next year brought a further batch of evildoers into the Mayor's Court, the offenders being the same as before - bullies, nightwalkers, protectors of women of ill-fame and keepers of disorderly houses. ${ }^{108}$

It may be noted that:

- The City authorities (usually constables and beadles) often acted as a result of: (a) a complaint being made to them, or (b) a petition being submitted to the mayor or alderman of the City of London; or (c) an information (this is, a legal complaint) being submitted to the Mayor's Court. These complaints etc tended to come from people who lived in the same street or close to the disorderly house in question;

- The brothel owner (also called the harbourer or receiver of prostitutes) ${ }^{109}$ was usually fined or required to provide surety for good behaviour. Sometimes, imprisonment was also imposed; ${ }^{110}$

- Nightwalkers (which included prostitutes and those suspected of visiting prostitutes) were usually fined or required to provide surety for good behaviour; ${ }^{11}$

- As to the brothel, its doors and windows were, sometimes, removed, to prevent further occupation and this seems to have been accepted as legal; ${ }^{112}$

- Because (as Coke noted) ${ }^{113}$ there was no distinct word for a brothel, in early times, reference was made to a 'disorderly house' (and later to 'bawdy house', 'house of ill fame', 'whorehouse', 'bordel' etc).

In conclusion, brothels - at least in London - were suppressed on the basis of being a common nuisance (with the exception of Southwark and Cock Lane where they were tolerated at various times). Brothel owners, prostitutes, procurers and nightwalkers (which included those suspected of visiting brothels) were also punished. As well as these, by London custom, it seems that adulterers and fornicators could be punished, even if this was not in the

\footnotetext{
and also if there be no power to arrest them, he (constable) can have aid of his neighbours (voisins) and they (neighbours) are compellable to (do) this by law.'

${ }^{105}$ Statute of Winton 13 Edw 1 st 2 c 4 (1285, rep) 'If any will not obey the arrest of the town [ie. nightwatchman], where night-walkers pass, they shall levy hue and cry upon them, and such as keep the town (viz. the bailiff or constable) shall follow with hue and cry with all the town and the towns near; and so hue and cry shall be made from town to town, until they are taken and delivered to the sheriff; and for arrestments of such strangers none shall be punished.'

${ }^{106}$ Being a 'harbourer' or 'receiver' of prostitutes and keeping a 'common bawdy house' seemed to mean the same thing (ie. keeping or maintaining a brothel).

107 eg. Thomas, n 73, pp 23-4 (presentment in 1298 before the Alderman of Allgate [Aldgate] ward in his wardmote that 'Peter Porthors is a receiver by night of unknown depraved men and prostitutes; and that in the rent of Ralph le Chapeleyn [Ralph the Chaplain] prostitutes and depraved men go about the City by night'. The jury held that Ralph knowingly harboured loose women against repeated warnings by his Alderman. He was put in mercy (ie. required to pay an amercement). See also p 74. See also AH Thomas, Calendar of Plea and Memoranda Rolls 1364-1381 (1929), p 151 (1373)(Zenobius Martyn, ...indicted... as a common bawd and associate of prostitutes...had admitted to his house men of ill-fame, evildoers, thieves and prostitutes. He was committed to prison.).

108 Thomas, n 53, p xxiv. See also Thomas, n 107, p 7 (1364)(woman sworn not to keep her house as a brothel).

109 See n 106.

${ }^{110}$ Jones, $\mathrm{n}$ 53, pp 13-4. See also p 72 (a man detained in prison in London 'because he had received in his house divers men and women for immoral purposes and for four years past and more had encouraged open fornication and adultery there...committed to the king's prison under the custody of the sheriffs until he should find mainprise...'). For the shaving of bawds, see White Book (1419), n 43, pp 394-5. Bawds were also called men and women of 'ill fame.' See also White Book, n 43, p 239 'that no courtesan [or] common brothel-keeper shall be residing within the walls of the City, under pain of imprisonment.

${ }^{111}$ See eg. White Book, $\mathrm{n} 43, \mathrm{p} 518$ 'A certain chaplain committed to the Tun, for being a nightwalker...'.

112 Thomas, n 73, p 211 (in 1305, a beadle went with neighbours to a house and removed doors and windows on the basis that prostitutes were housed there. A jury upheld this action and also ordered the removal of any prostitutes still there). See also pp 218-9 (in 1300, doors and windows of a house in Cokkes [Cock] Lane were removed since it was occupied by prostitutes). See also p xx. See also Thomas, n 107, p 57 (1366) broke into the house of a woman of bad character (male condicionis) and carried away doors and windows of her chamber).

${ }^{113}$ See n 51.
} 


\section{context of a brothel. This is now considered.}

\section{Offences of Fornication \& Adultery 114}

Apart from prostitution, Coke noted that - in ancient times - adultery and fornication were punished by fine and imprisonment and they were inquirable in tourns and leets by the name of 'letherwite' (or lairwite). ${ }^{115}$ The latter word is Anglo-Saxon. The extent to which this fine was collected after the Norman Conquest in 1066 is unclear, since fornication and adultery tended to be treated as ecclesiastical, rather than criminal, offences. That said, in London (by which one means the City of London), it appeared that local custom ${ }^{116}$ made it an offence to commit fornication or adultery. This is now discussed.

\section{(a) Adultery \& Fornication}

In Gylys $v$ Watterkyn (1486) ${ }^{117}$ pursuant to an information - and acting in accordance with a supposed London custom - a constable took a parish beadle and others to the house of man committing adultery. Arresting him, the constable imprisoned him in the London counter (a prison). A subsequent action by the man against the constable for false imprisonment did not proceed to judgment.

- Doubtless, in part, this was because there was uncertainty among the judges whether the asserted London custom should be upheld as reasonable;

- That said, this London custom does seem to have existed in earlier times and Preest noted that the punishment of parading adulterers and fornicators around London, was encouraged by the Lollards in 1352. ${ }^{118}$ Further, adultery seems to have been an offence. For example, in 1446. ${ }^{119}$ Also, fornication. For example, in 1422. ${ }^{120}$ Lambard, in his standard text on the Duties of Constables published in 1582, sanctioned this London custom referring to Gylys $v$ Watterkyn (1486). ${ }^{121}$ It was also noted by Littleton (writing c. 1644). ${ }^{122}$

\footnotetext{
${ }^{114}$ Mirror of Justices (c. 1290), n 9, p 29 'Stuprum is the felonious taking away of a woman's maidenhood ('despuceler femme'). Fornication is the defiling of an unmarried woman who is already corrupted. Adultery is the defiling of another man's wife....' As to the meaning of these words, in Anglo-Norman, 'pucele' meant a girl (see Anglo-Norman dictionary, n 50). For 'Stuprum' see n 57.

${ }^{115}$ Coke, $\mathrm{n}$ 10, vol 3, p 205. Letherwite was spelt in a variety of ways. Coke thought that the word derived from 'legre or logre for a bed.' Cowell, $\mathrm{n}$ 52, (lairwice) 'Poena vel mult a offendentium in adulterio vel fornacatione, ['penalty or fine for those committing the offences of adultery or fornication'] which privilege did anciently belong to some lords of manors, in reference to their villains and tenants, which Fleta, lib 1, cap 47 seems to infer [I have not been able to locate this reference]. See also Coke, n 10, vol 4, p 206 [a mis-reference to vol 3, p 206].' See also T Blount, A Law Dictionary and Glossary (printed by Elizabeth Nutt \& R Gosling, $3^{\text {rd }}$ ed, 1717) (lairwite) 'a fine, or custom of punishing offenders in adultery and fornication, which privilege did anciently belong to the lords of some manors, in reference to their villains and tenants...' See also Burford, n 49, p 85.

${ }^{116}$ By Jacobean times, the courts seem to have been reluctant to uphold local customs since they were contrary to the general law as well as being partial. City of London's Case (1610) 8 Co Rep 127 (77 ER 658) per Coke CJ 'There are divers customs in London which are against common right, and the rule of the common law...'. Day v Savadge (1614) Hobart 86 (80 ER 235) 'such customs as are of the nature of local laws, peculiar laws for that city, general to all the citizens, differing from the general law of the kingdom.'

${ }^{117}$ See 1 Hen 7 pl 3 fo 6a-7b, Seipp Index, n 54, no 1486.003. Coke, n 10, vol 3, p 205 'See the case of 1 Hen 7 [ie. the case Gylys $v$ Watterkyn] the custom of London for entering into a house, and arresting of an advowtrer, and carrying her [it should say him] to prison'.

${ }^{118}$ D Preest (trans), The Chronica Maiora of Thomas Walsingham 1376-1422 (Boydell Press, 2005), p 183. See also McBain, n $45, \mathrm{p} 47$. For a campaign against adultery (and the bringing of cases before the Mayor's Court) in 1381-2 when Richard Northampton was mayor of London, see AH Thomas, Calendar of Select Pleas and Memoranda of the City of London 1381-1412, p 148.

119 Jones, n 53, p 88 (1446) 'Return that by the custom of the City from time immemorial any person suspected of public adultery, rape, contumely, nightwalking, rebellion or disturbance of the peace ought to be and had been taken and detained in prison until he found sufficient security to await whatever the law and custom of the City should demand in the case of conviction, and the said Henry, having been presented in [a wardmote] as a public and notorious adulterer who had been living in his own house for a long time in adultery... and shamelessly refused to end his conduct thus setting a pernicious example whence many disturbances of the peace had arisen, the said Henry had been taken and detained until he found security to await whatever the law and custom of the City should require in the case of conviction; nevertheless he would be brought into court as directed.' (italics supplied)

${ }^{120}$ eg Thomas, $n$ 53, (inquest of 1422) 'They say also that Thomas Bird... at many times committed fornication with divers unknown women...Also, they say that Alice, wife of John Cheyney, and Isabel Cobham on 20 Sept. and on many other occasions committed fornication with two priests and afterwards with other divers unknown men, and that they are common strumpets.' See also other instances in this text. In the wardmote inquests there are often references to fornication.

${ }^{121}$ Lambard, n 103, p 18 (1582 ed) 'And I like well of their opinion, which do hold, that if information be given to any such officer, that a man and a woman be in adultery, or fornication together then the officer may take companion with him, and that if he find them so, he may carry them to prison.' Repeated in the 1640 edition, p 17.

122 JH Baker \& SFC Milsom, Sources of English Legal History (Butterworths, 1986), p 310 cited The Newe Littleton (c.1644)(Lord Littleton's Legal Digest) which stated 'And by a special custom in London if information be given unto any constable there that any within his jurisdiction is with any woman in adultery, he may call the beadle and others of the same parish and go unto the house, and if they find the man in adultery,
} 


\section{(b) Priests - Adultery}

It also appears to have been a London custom that - if a chaplain (priest) kept a woman in his chamber (room) suspiciously - a man might come to the chamber with the constable (beadle) of the ward and search. Reference may be made to a case in 1400. ${ }^{123}$ The White Book of the City of London (1419) also provides:

If any priest shall be found with a woman, let him be taken unto the Tun [prison] on Cornhill, with minstrels. And if he shall be so found three times, let him forswear the City for ever...

if any adulteress shall be found with a priest or with a married man, let them both be taken unto the Compter of one of the sheriffs, or unto Newgate, and from thence to the Guildhall, before the mayor and aldermen, and there arraigned; and if they shall then be lawfully attainted thereof, let them to taken to Newgate; and there let the said adulterer and adulteress be shaved, like an appealer; and from thence, with minstrelsy, let them be brought through Cheap unto the same Tun, there to remain at the will of the mayor and aldermen....

if a single woman shall be found in company with a priest, let them both be taken unto the compter of one of the sheriffs, and from thence unto the said Tun, there to remain at the will of the mayor and aldermen. 124

It appears that - between 1400-40 - no less than 60 clerks in holy orders were taken in adultery ${ }^{125}$ and put in prison by ward beadles. ${ }^{126}$

Whatever may have been the position as to these London customs in early times, Coke (published in 1641) stated that offences relating to fornication and adultery belonged to the ecclesiastical court. ${ }^{127}$ The effect was the demise of such customs - although various legal writers continued to refer to it for some time thereafter. ${ }^{128}$

In conclusion, by the $17^{\text {th }}$ century, fornication and adultery were no longer treated as criminal offences.

\section{Disorderly Houses - Other Instances}

Apart from references to brothels - as well as to inns which masqueraded as such ${ }^{129}$ - and houses where adultery and fornication were being carried on, it is difficult to find the expression 'disorderly house' covering anything else. There is one exception to this:

- In early medieval times, thieves, robbers and other criminals - as well as prostitutes and their procurers were often referred to as persons of 'bad' or 'ill fame' (ie. bad reputation);

- In the case of common inns (as well as common taverns) ${ }^{130}$ used as the haunt of thieves and other criminals, pleadings often refer to the 'bad fame' of the persons who gathered there. ${ }^{131}$ Such could be treated as 'disorderly houses' and suppressed as a common nuisance - not least since, by law, common

to take and conduct him unto the compter and there leave him in prison until he shall pay so much or be there delivered by the due course of the law; and this is held to be a good custom...' See also McBain, $\mathrm{n} 45, \mathrm{p} 47$

${ }^{123}$ McBain, n 45, p 47 referring to YB 2 Hen 4, pl 51, fo 12b, see Seipp Index, n 54, no 1400.051 (an action of trespass was brought by a priest. The defendant (his fiancée) entered the priest's chamber (room) to recover property belonging to the priest, including a ring).

${ }^{124}$ White Book, n 43, pp 395-6.

${ }^{125}$ RR Sharpe, London and the Kingdom (Longmans, 1894), p 255. See also RR Sharpe, Calendar of Letter-Books of the City of London, Letter-Book I 1400-1422 (1909), pp xlii-iii \& 273-87 (schedule of those taken in adultery in the City of London between the years 1401-39, including many priests). Laughran, n 55, p 62 'Priests who frequented prostitutes were charged with adultery, since they were violating their 'marriage' vow of chastity to the church.' It is likely that there was considerable resentment against priests who were required by the Catholic church not to marry and to remain chaste. See Karras, n 51, p 17. See also prohibition on priests to associating themselves with women promulgated at the council of London (AD 1102), see English Lawsuits from William I to Richard I, Selden Society, vol 106, pp 137-8.

${ }^{126}$ Ibid. Accusations of fornication with priests were common eg. Riley, n 43, pp 566-7 (eg. 1406, pillory for a chaplain caught in adultery with a tailor's wife by the bedel (beadle)). For a case where the solicitation of chastity being accompanied by imprisonment and force became a criminal matter, see Abbot of St Alban's Case (1482) Seipp Index n 54, 1482.115 (1482) 22 Edw 4 pl 47 fo $20 \mathrm{a}-20 \mathrm{~b}$.

127 Coke, n 10, vol 3, p 205 'But now these offences belong to the ecclesiastical court.'

128 Thus, Dalton (in 1619) referred to it (see 8).

129 Laughran, n 55, p 67 'some inns were already brothels. Two ordinances, one from 1436 and another from 1470, provide evidence of these circumstances, and the latter one states explicitly that an inn called the Castell uppon the Hoope was operating as a whorehouse.' See also RR Sharpe, Calendar of Letter-Books of the City of London, Letter-Book K (1911), p 316 (in 1446, the mystery of hostelers complained to the mayor and alderman that many inns did not have open signs and some were 'vicious houses called stews' (spelling modernized)).

130 'Common taverns' comprise the modern day public houses. It seems that many taverns were blind taverns (ie. pubs without a sign) which criminals and prostitutes frequented. For an indictment against a man of evil behaviour for keeping a blind tavern without a sign and for receiving and lodging lewd persons, see W West, Symboleography (London, 1641, rep Garland Publishing, 1979 ), pt 2, p 137.

131 See, eg, the references to 'ill fame ' and 'bad character' in n 101 and the reference to 'ill fame' in $\mathrm{n} 83$. 
innkeepers were otherwise obliged to accept every traveller and be responsible for the same ${ }^{132}$ unless they were "notoriously of obviously of bad repute. ${ }^{133}$ The White Book of the City of London (1419) provides:
And whereas thieves and other persons of light and bad repute are often, and more commonly, received and harboured in the houses of women of evil life within the City than elsewhere, through whom evil deeds and murders, by reason of such harbouring, do often happen, and great evils and scandals to the people of the City - the king doth will and command, that from henceforth no common woman shall dwell within the walls of the city. And if any such shall hereafter be found within the City residing and dwelling, she shall be imprisoned forty days. And let the Warden cause search to be made throughout the City in the best manner that he shall see fit, where such women are received, and who they are; and then, when they shall be found, let their limits be assigned unto them. ${ }^{134}$

- As to private houses (ie. not common inns or taverns or brothels) London custom enabled the punishment of adulterers and fornicators (see 5). ${ }^{135}$ However, one presumes that a private house could only be treated as a 'disorderly house' if there was an element of 'open house'. That is, it was being used as a brothel or the regular haunt of thieves or other criminals. The mere fact that two or three people who lived in a house happened to have been convicted of a criminal offence at some time or other (probably, a fairly regular occurrence) would not have been a ground to so treat it.

In conclusion, a 'disorderly house' in medieval times included a common inn or a common tavern, the haunt of thieves or other persons of 'bad fame' (ie. criminals).

\section{Conclusion - 'Disorderly House' in Medieval Times}

In conclusion, in medieval times, the following seems fairly clear, that:

- Brothels were regarded as boarding 'houses' ('bordels' in Anglo-Norman) - the same as any other house. However, they were also categorized as 'disorderly houses' - permitting the criminal law to suppress them as a common nusiance (apart from those in Southwark and Cock Lane, which were tolerated from time to time);

- Common Inns (hotels) as well as common taverns which were - in effect - brothels were also treated as 'disorderly houses'. Also, common inns and common taverns, the haunt of persons of ill-fame, were treated as 'disorderly houses;,"136

- London Customs. There were London customs which permitted the criminal punishment of fornicators and adulterers, including unchaste priests. After c. 1630, save for during some of the Civil War (164960) ${ }^{137}$ these customs were no longer upheld, although legal writers continued to refer to them;

- Private Houses. If a private house was, in effect, a brothel, it could be treated as a 'disorderly house'. If it could be shown to be the regular haunt of thieves and criminals, then, likely, it could also be treated as a 'disorderly house.' However, to be treated as a 'disorderly house' it had to 'common' (ie. open to the public in some way).

\section{Disorderly Houses: Legal Writers - 17th Century}

The position would appear to be as follows:

- The earliest dedicated text on English criminal law, Staunford, Plees del Coron (1574), ${ }^{138}$ did not deal with disorderly houses, nor brothels. Nor did Pulton, in his De Pace Regis et Regni (1609); ${ }^{139}$

\footnotetext{
${ }^{132}$ The liability of the common innkeeper for their goods (and horse) while staying at the inn was strict, see McBain, $\mathrm{n} 45$.

${ }^{133}$ See $\mathrm{n} 44$ (judgment of Belknap CJ in 1384).

${ }^{134}$ White Book, n 43, pp 246-7. See also p 287 (articles of the wardmote 'that no woman of lewd life, bawd, courtesan, or common scold be resident in the ward.').

${ }^{135}$ While brothels (and common inns and common taverns used for prostitution) could be dealt with as 'disorderly houses' and the frequenters of brothels (nightwalkers) who fled from the nightwatchman or a constable could be arrested and required to provide surety of their good behaviour, this still left people (including priests and monks) who invited prostitutes back to their houses, for which see 5(b).

${ }^{136}$ Common inns did not need a licence to operate, see n 148. Thus, this was likely the only means to regulate them. For the regulation of common alehouses by JP's from 1552, see Webb, n 35, p 7 et seq.

${ }^{137}$ Blackstone notes the position in 1650, see 10(b).

${ }^{138}$ W Staunford, Les Plees del Coron (Richard Tottell, $1^{\text {st }}$ ed, 1557, $2^{\text {nd }}$ ed, 1607), reprinted by the Law Book Exchange.

${ }^{139}$ F Pulton, De Pace Regis et Regni (London, Company of Stationers, 1609), reprinted by the Law Book Exchange.
} 
- This is not especially surprising since 'lewdness' or 'lechery' ${ }^{140}$ was, generally, either a matter for the ecclesiastical courts or for the courts leet or sheriff tourns which dealt with more minor criminal offences. Thus, texts dealing with criminal law in general would not treat of disorderly houses.

Dalton - whose seminal work on The Countrey Justice was first published in 1618 and continued until 1746 - also did not deal with disorderly houses. However, he did note that Justices of the Peace ('JP's') could require various persons to provide surety for their good behaviour (bon porte). He stated: ${ }^{141}$

it [surety for good behaviour] is also grantable against such as be of evil name and fame generally, but more specifically against all such as are defamed or detected in any of these particulars following:

1. First, against those that are greatly defamed [ie. are alleged to be of ill-fame] for resorting to houses suspected to maintain adultery or incontinency. ${ }^{142}$

2. Also against the maintainers of houses commonly suspected to be houses of common bawdry. One that had such lewd women found in his house was bound to his good behaviour by Wray, Anderson and Manwood 28 Eliz. [1585] ${ }^{143}$

3. Also against common whoremongers [ie. procurers] and common whores; for (by good opinion) avowtry or bawdry is an offence temporal as well as spiritual, and is against the peace of the land. ${ }^{144}$ Upon information given to a constable, that a man and a woman be in adultery, or fornication together (or that a man and a woman of evil report, are gone to a suspected house together, in the night) the officer may take company with him, and if he find them so, he may carry them to prison; or he may carry them before a justice of peace, to find sureties for their good behaviour. ${ }^{145}$ (wording divided and spelling modernized for ease of reference)

As previously noted (see 4(d)), Coke, in the third volume of his Institutes of the Laws of England (published 1641) under the chapter heading (De Lupanaribus et Fonicibus, etc)(Of Brothels and Stewhouses etc) ${ }^{146}$ - and under the

\footnotetext{
${ }^{140}$ See OED, n 51, (lechery) 'habitual indulgence of lust, lewdness of living'. The word may have derived from the Anglo-Saxon 'letherwite', see $\mathrm{n} 115$. OED, $\mathrm{n} 51$ (lewdness). This, originally, had meanings of ignorance and want of good breeding as well as wickness and evil behavior. It was only later that it came to mean 'lasciviousness, lascivious behavior.' OED, n 51 (lasciviousness) '1a Inclined to lust, lewd, wanton'. 1b inciting to lust or wantonness.'

${ }^{141}$ M Dalton, The Countrey Justice (Societie of Stationers, $2^{\text {nd }}$ ed, 1619), p 172.

${ }^{142}$ Dalton, n 141, cited 13 Hen $7 \mathrm{pl} 10$ fo 10b (1497), Seipp Index, n 54, no 1497.021. This was an action for assault, battery and false imprisonment brought by a nightwalker against a man requested by a constable to help detain him. The action was dismissed by the judges. Seipp records 'Defendant pleaded that a woman held a house in the same vill, that she kept suspicious company (garda suspeceonneux gens), that is, a common bawd, that plaintiff oftentimes resorted to the same house suspiciously with women of bad reputation (male fame), and defendant named the women, so that a constable of the vill came to defendant, that the constable asked defendant to aid the constable to arrest plaintiff to find surety for plaintiff's good comportment (bon porte) and reputation (nom), so that defendant came with the constable at midnight and found plaintiff suspiciously in the same place, by force of which defendant and the constable arrested (prindre) plaintiff, and put plaintiff under guard, which was the same assault, battery, and imprisonment of which plaintiff had conceived plaintiff's action. This was held a good justification by all the justices.' See also J Baker, The Oxford History of the Laws of England (OUP, 2003), vol 6, p 286 which cites the case of Corby $v$ Alsoppe (1507)(London custom asserted of being able to arrest persons for frequenting a bawdy house).

${ }^{143}$ Dalton, n 141, cited R Crompton, L'Office et Authoritie des Iustices de Peace (Companie of Stationers, London, 1617, Crompton edited this text of Sir Anthony Fitzherbert, the $1^{\text {st }}$ ed of which was published in 1538), p 140 of which stated 'Un que aver male femes in son meason in Londres, fuit commit tanque fuit lie al bon port, et ceo fuit issent order sessions al Newgate 28 Eliz per Wray \& Anderson chiefe iust et Manwood chiefe Baron.' ('One who had prostitutes in his house in London, was committed, also he was required to provide surety for his good behaviour, and this was ordered at a sessions at Newgate 1585 by Wray, Anderson, chief justices, and Manwood, chief baron.'). Sir Christopher Wray was Chief Justice of the King's Bench from 1574-92, Sir Edmund Anderson was Chief Justice of the Common Pleas from 1582-1605 and Sir Roger Manwood was Chief Baron of the Exchequer from 1578-92. See J Sainty, The Judges of England 1272-1990 (pub. Selden Society, 1993). Crompton also noted 'Mes justices de peace ne auters justices le roy ne poient punisher lechery, mes le ordinary, quod vide Fitz Nat bre fol 50.51'. ('But justices of the peace nor other justices of the king cannot punish lechery, only the ordinary [bishop] for which see Fitzherbert, Natura Brevium, fo 50, 51.' The reference is to writs of consultation. See eg. A Fitzherbert, The New Natura Brevium (printed by E Nutt \& R Gosling, 1718), p 112 et seq (writs of consultation).

${ }^{144}$ Dalton, n 141, cited 1 Hen 77 (Gylys v Watterkin, see n 117). Also, '27 Hen 8 14' which appears to be a reference to $27 \mathrm{Hen} 8 \mathrm{pl} 4$ fo $14 \mathrm{a}-\mathrm{b}$ (1535) (action on the case for defamation. Fitzherbert JCP noted that it would be defamatory to accuse a person of keeping a brothel (' $t$ tient bawdry').

${ }^{145}$ Dalton, $\mathrm{n}$ 141, cited the case in 1497 referred to in $\mathrm{n}$ 142. Also, to Brooke, $\mathrm{n} 21$ (title 'Traverse'), no 432 (Home de male fame ove femes. Nightwalkers) which abridged it.

${ }^{146}$ JH Baxter et al, Medieval Latin Word-List (rep. 1955) cites the use of the word 'domus lupanaria' in 1541 (house of ill repute) and 'lupino' in c. 1123 (to frequent houses of ill repute). It also seems that 'lupanar' and 'lupanaria' were used as words for brothels as early as 1450-60. The word 'bordello' would have been imported from the Spanish word for a brothel. See also Lewis, n 52 which refers to 'lupa' (she wolf), 'lupanor' (house of ill repute) and 'lupinaris' (belonging to, or characteristic of, a lewd woman). For 'fornicibus' and its derivation from 'fornix', a brothel, see also n 52.
} 
sub-heading 'Brothel-houses, Estuis, Bordellos' - indicated that brothel keepers were punishable with a fine and imprisonment, since the keeping of a 'house of bawdry or stews, or brothel-house' was a common nuisance.

In conclusion, disorderly houses prior to 1716 invariably referred to unauthorized brothels as well as to houses (especially common inns and taverns) the haunt of criminals.

\section{Legal Writers: Hawkins: 1716 - 1824}

The first edition of William Hawkins, Treatise of the Pleas of the Crown in 1716, is the first systematic analysis of the offence of common nuisance. Under the title of 'Common Nuisance', Hawkins discussed the following:

\section{(a) Common Inns}

Hawkins stated:

It seems to be agreed, that the keeper of an inn may by the common law be indicted and fined, as being guilty of a public nuisance, ${ }^{147}$ if he usually harbour thieves, or persons of scandalous reputation, ${ }^{148}$ or suffer frequent disorders in his house, or set up a new inn in a place, where there is no manner of need of one, to the hindrance of other ancient and well governed inns, or keep it in a place in respect of its situation, wholly unfit for such a purpose. ${ }^{149}$

Hawkins also indicated that a common innkeeper could be indicated for refusing to provide board and lodging to a traveller. ${ }^{150}$ Authority to this can be traced no further back than to a case in 1465 in which:

it was said that said by all the justices that if a common innkeeper will not lodge me, I shall not have an action against him, ${ }^{151}$ but shall complain to the ruler of the vill [ie. a constable] and he shall give me direction therein.

Whether this statement derived from an earlier judicial statement in 1384 is unclear. ${ }^{152}$ What does seem clear, however, is that this was a separate offence and not a common nuisance as such (and, today, it is so treated). ${ }^{153}$ Thus, it is not an instance of keeping a disorderly house. ${ }^{154}$

\footnotetext{
${ }^{147}$ Hawkins referred to $R v$ Collins, Bennet, Sanford \& Gibbs (1623) Palm 374 (81 ER 1130) and 2 Rolle Reports 345 (81 ER 842) where the court held that it was not a common nuisance to establish an inn or put up a sign (since no licence was required to operate an inn). For it to be a common nuisance, the indictment had to allege that the inn was 'burdensome' (because the great number of other inns close to it) or that it did 'harbour thieves, et auters de male report etc' ('harbor thieves and persons of ill fame etc'). The court also noted that in ancient times there were no inns but what [those which] were allowed in eyre, but in present times if a man put up a sign and harboured guests, it was deemed a 'common' inn. See also The Laws concerning Travelling etc (sold by J Ferryman, 1718) p 105.

${ }^{148}$ Hawkins cited M Hale, Pleas of the Crown (London, printed for assigns of Richard Atkins and Edward Atkins, 1685 ed), p 146 'Any person may erect a common inn, so be it not ad nocumentum [a nuisance] 1. In respect of their multitude, when there are enough ancient inns before. 2 In respect of the inconvenience of the place or situation. 3. In respect of disorders there permitted. All which are common nuisances and may be presented and fined.' Hawkins also cited Dalton, ch 7 (eg. n 141, (1619 ed), p 27 'Common inns are appointed for travellers and wayfaring men... and therefore if any inn-keeper shall suffer persons inhabiting in the same town, or any other persons (contrary to the statute [7 Jac 10 (1609) c10, rep 1828]) to be usually tipling in his house, such an innkeeper may be accounted as well an alehouse-keeper, as an inn-keeper, and may be bound by recognis[ance] with sureties, for the keeping of good order, as alehouse-keepers are; and so judge Warberton delivered it in his charge at Cambridge Assizes, ann dom.1613. Or else it seemeth they may be committed as alehouse-keepers without licence (by two justices of the P[eace] as aforesaid.' If an inn was not 'commune' (ie. not a common inn), then it was only a 'domus' (a private house), see Mason \& Grafton (1614) Hob 245 (80 ER 391).

${ }^{149}$ Hawkins, n 4, vol 1, p 225. For a forms of indictment for : (a) (in 1672) for keeping a disordered alehouse, see W(J), Officium Clerici Pacis (London, $2^{\text {nd }}$ ed, 1705), p 186, (b) (in 1666) against a common barretor and his wife, being a scold, for keeping a private tavern (a blind tavern) and entertaining suspicious persons, ibid, p 232; (c) against a tavern keeper (victualler) for entertaining whores, vagabonds and idle suspected persons, ibid, p 247.

${ }^{150}$ Ibid. See McBain, $\mathrm{n}$ 4, where this offence is considered in detail.

${ }^{151}$ There was uncertainty as to whether there was a civil remedy. It was asserted there was in 1460 . However, it was not finally settled that a civil action could be sustained until 1588. See McBain, $\mathrm{n} 4$, pp 93-4.

${ }^{152}$ See $\mathrm{n} 44$ (Belknap CJ). I do not believe that this offence could have been created in any case prior to 1290, since Fleta (c 1290), n 8, vol 72, p 51 mentions that justices in eyre could investigate 'those who have wrecked vengeance on those who have refused them food or lodging'. If there had been an obligation on a common innkeeper (which term Fleta also does not mention) then Fleta would likely have referred to it. Further, the strict liability of the innkeeper for the goods of the guest was only recognized by the courts c. 1368 and it is unlikely that an obligation to provide board and lodging would not have been mentioned then. Thus, it seems likely that such an offence only arose in 1465 or, at least, not earlier than 1368. Indeed, Letter-Book F, n 80, makes a number of mentions of 'hosteler' and 'hostiller' but with no prefix of 'common' before them.

${ }^{153}$ Thus, for example, Goddard CJ in Rv Higgins [1948] treated it as a separate offence and not as an offence of 'common nuisance' or that of 'keeping a disorderly house'. See McBain, n 45, p 95.

${ }^{154}$ For this reason this offence is not further considered. In any case, it is asserted that it is obsolete - the civil remedy is sufficient. See McBain, ns $4 \& 45$. For an indictment of 1672 for keeping a bawdy house (communem domum luponar'), see W(J), n 149, p 176.
} 


\section{(b) Brothels}

In respect of brothels (bawdy houses), Hawkins stated:

The offence of keeping a bawdy-house being of so gross a nature, and there being also so few questions relating to it worth considering, I shall pass it over with these following observations. 1.That it comes under the cognisance of the temporal law as a common nuisance, ${ }^{155}$ not only in respect of its endangering the public peace by drawing together dissolute and debauched persons, but also in respect of its apparent tendency to corrupt the manners of both sexes, by such an open profession of lewdness... offenders of this kind are punishable not only with fine and imprisonment, but also with such infamous punishment as the court in discretion shall deem proper. ${ }^{156}$

\section{(c) Common Gaming Houses, Rope Dancers, Playhouses}

Hawkins stated:

There is no doubt but that common bawdy houses are indictable as common nuisances, as hath been more fully shown in the foregoing chapter, also it hath been said, that all common stages for rope dancers, and also all common gaming houses, are nuisances in the eye of the law, not only because they are great temptations to idleness, but also because they are apt to draw together great numbers of disorderly persons, which cannot but be very inconvenient to the neighbourhood...

Also it hath been holden, that a common playhouse may be a nuisance if it draw together such numbers of coaches or people etc. as prove generally inconvenient to the places adjacent, and it seems to be a proper distinction between play houses and the nuisances mentioned in the foregoing section, that playhouses having been originally instituted with a laudable design of recommending virtue to the imitation of the people, and exposing vice and folly, are not nuisances in their own nature, but only become such by accident, whereas the others cannot but be nuisances. ${ }^{157}$

'Rope dancing' is mentioned is due to the fact that (along with tumbling, comics and other circus acts) it seems it was, often, undertaken on play stages. ${ }^{158}$ Also, 'rope dancer' was, often, a common euphemism for a harlot. ${ }^{159}$

\section{(d) Disorderly Houses Act 1751}

This Act, ${ }^{160}$ in its preamble, stated:

whereas the multitude of places of entertainment for the lower sort of people is another great cause of thefts and robberies, as they are thereby tempted to spend their small substance in riotous pleasures, and in consequence are put on unlawful methods of supplying their wants, and renewing their pleasures...

It then provided that, as from 1 December 1752:

any house, room, garden, or other place kept for public dancing, music, or other public entertainment of the like kind, in the cities of London and Westminster, or within twenty miles thereof, without a licencee... shall be deemed a disorderly house or place... ${ }^{161}$

\footnotetext{
${ }^{155}$ Hawkins, n 4, vol 1, p 197 'a common nuisance may be defined to be an offence against the public, either by doing a thing which tends to the annoyance of all the king's subjects, or by neglecting to do a thing which the common good requires.' Also, 'But annoyances to the interests of particular persons are not punishable by a public prosecution as common nuisances, but are left to be redressed by the private actions of the parties aggrieved by them.'

${ }^{156}$ Ibid, p 196. 'Infamous punishment' would seem to refer to the pillory or tumbrel (ie. carting whores). It may be noted that G Jacob, The Modern Justice ( $3^{\text {rd }}$ ed, 1720) (lewdness), pp 277-8 did not deal with disorderly houses but only referred to bawdy houses, clearly treating them as one and the same. This was probably (strictly) more appropriate than the approach of Hawkins which was to also refer to common gaming houses, places where rope dancers and common playhouses as forms of disorderly house, when they were suppressed more as common nuisances in those times (it not being necessary to prove that were houses of ill fame with lewd women). For an indictment for keeping a bawdy house, Ibid, p 279.

${ }^{157}$ Ibid, p 198.

${ }^{158}$ OED, n 51 (rope dancing) 'One who 'dances' or balances on a rope suspended at some height above the ground: a funambulist.' See also Skinner 625 (190 ER 281) at p 1196 (rope dancing was held to be a nuisance per se in the case of Jacob Hall, c. 1670). For Jacob Hall (1662-81), a well known tightrope walker, see Oxford Dictionary of National Biography. See also Viner, n 27, title, Nuisances, pp 24, 39.

${ }^{159}$ See $\mathrm{n} 94$.

${ }^{160} 25$ Geo 2 c 36 (rep 2008) made perpetual by 28 Geo 2 c 19 (Act of 1755, rep 1867). See also 58 Geo 3 c 70 (1818, rep 1965).

${ }^{161}$ In the case of an licensed establishment the Act empowered a constable to enter (and seize) every person therein that 'they may be dealt with according to law.' Persons keeping such an establishment were liable to a fine of $£ 100$. For a case under this Act, see $R v$ Tucker (1877) 2 QBD 417 (ice rink in which music was played in the evening was held to be a place for entertainment for the purposes of the Act and, thus, required a licence).
} 
As a result, playhouses and other public places of entertainment in London were treated (by statute) as 'disorderly houses', if unlicensed.

\section{(e) Common Houses used for Cock Fighting}

In Higginson (1762), the court held that a 'disorderly house' included a 'common' house where the owner permitted, for money, the 'fighting of cocks, boxing, playing at cudgels and misbehaving'. ${ }^{162}$ The indictment charged that Higginson:

did keep and maintain and yet [still] doth keep and maintain a certain common ill-governed and disorderly house; and in the said house, for his own lucre and profit, certain evil and ill-disposed persons, of ill name and fame and of dishonest conversation, do frequent and come together there and the other said other days and times, there unlawfully and wilfully did cause and procure; and the said persons in the said house, then and the said other days and times, there to be and remain fighting of cocks, boxing, playing at cudgels and misbehaving themselves, unlawfully and wilfully did permit and yet [still] doth permit: to the great damage and common nuisance of all the subjects of our lord the king inhabiting near the said house; and against the peace of our said lord the king, his Crown and dignity. ${ }^{163}$ (italics supplied)

The reference to a 'common...house' indicates that the place in question was a tavern or inn to which the public has access (ie. an open house) and not a private house. ${ }^{164}$

- It may be noted that a prior case of cock-fighting in a 'common cock-pit' had been treated as an unlawful game pursuant to an Act of 1541. Thus, in Howel (1675), ${ }^{165}$ it was stated: 'The defendant being convicted of keeping a common cock-pit six days the court conceived it an unlawful game, and took their measures by $33 \mathrm{H}$ cap $[9]^{166}$ of 40 s a day, though the indictment were at common law, and he was fined 121';

- The indictment was probably framed for keeping a disorderly house. ${ }^{167}$ However, the court preferred to treat the matter as one of carrying on an unlawful game pursuant to An Act for maintenance of Archery and Debarring of Unlawful Games 1541, section 8 of which prescribed a penalty of 40s per day for those who kept any unlicensed 'common house' in which there were played games (called a 'gaming house'); ${ }^{168}$

- Thus, in this case, instead of convicting under the common law, the court was able to substitute a higher fine. The 1541 Act was a revenue raising device for Henry VIII (1509-47). Hence, the high fines. ${ }^{169}$

\section{(f) Hawkins - Final Edition: 1824}

In the first edition of his work in 1716, Hawkins did not refer to a 'disorderly house' as such. However, by the final edition of his work (published in 1824) he did. Under the title 'Offences against the Public Economy' and under the heading of 'Common Nuisances, ${ }^{, 170}$ in separate sub-headings, Hawkins discussed:

- nuisances relating to public houses (ie. common inns); ${ }^{171}$

- of keeping a bawdy-house; ${ }^{172}$ and

- of keeping, and frequenting, a common gaming house. ${ }^{173}$

\footnotetext{
1622 Burr 1232 (97 ER 806). For the tendency of innkeepers to allow cockfighting on their premises, see Webb, n 35, p 58 (Lancashire Justices in Quarter Sessions in 1782).

${ }^{163}$ At p 1233. See also J Chitty (Jun), Practical Treatise on the Criminal Law (pub. Edward Earle, 1819), vol 4, p 673.

${ }^{164}$ See also Anon (1752) 3 Atk 750 (26 ER 1230 )(an injunction to prevent the construction of a house to innoculate for smallpox, as being a common nuisance, was rejected). Lord Hardwicke LC noted that 'It ... becomes a public nuisance when it affects many persons, though it may likewise at the same time be of a private nature too as in the case of a hole in the king's highway'.

$1653 \mathrm{Keb} 510$ (84 ER 849).

${ }^{166}$ A reference to 33 Hen 8 c 9 (1541 rep by the Betting and Gaming Act 1960).

${ }^{167}$ The judgment only comprises 3 lines and so little can be said.

${ }^{168}$ For those who frequented unlicensed common gaming houses, the fine was $6 \mathrm{~s} 8 \mathrm{~d}$. Section 9 provided that JP's could enter gaming houses and arrest the keepers and parties and take surety for their good behaviour. Section 15 contained a proviso that servants could play at cards etc with permission of their masters. For early cases in the City of London for punishing those playing at dice and gaming, see Thomas, n 107, pp $89,115 \& 139$.

${ }^{169}$ Section 16 of the Act provided that noblemen etc could licence playing cards, dice tables, bowls, tennis etc in their houses.

${ }^{170}$ Hawkins, n 4, (1824 ed), vol 1, p 692 'Common nuisances are offences, under the degree of capital, more immediately against the subject, not amounting to an actual disturbance of the peace, which may be committed by private persons without any relation to an office.'

${ }^{171}$ Ibid, $\mathrm{p} 714$. The wording in the 1824 edition differed little from the 1716 edition (108 years previously).

${ }^{172}$ Ibid, $\mathrm{p} 716$. The wording in the 1824 edition differed little from the 1716 edition.
} 
Hawkins also had a separate title 'Of keeping a Disorderly House, ${ }^{174}$ under which he only referred to the various sections of the Disorderly Houses Act 1751.

In conclusion, the concept of a 'disorderly house' prior to 1716 (when Hawkins first wrote) effectively only covered: (a) brothels; and (b) common inns and taverns - when prostitution was carried on there or which were the haunt of thieves, as well as, (c) places where fornication and adultery were committed. In 1716, Hawkins grouped together as 'common nuisances', brothels as well as (d) common inns, (e) common gaming houses; and (f) common playhouses. The Disorderly Houses Act 1751 then held (g) London playhouses; and (h) other places of entertainment in London, if unlicensed, to be 'disorderly houses'. Finally, in 1762, a court case held: (i) a common house where cockfighting was carried on, to be a 'disorderly house'. In short, the legal concept expanded.

\section{Legal Writers - Burn (1755) \& Blackstone (1765-9)}

\section{(a) Burn (1755)}

Burn, in the first edition of his Justice of the Peace and Parish Officer in 1755, ${ }^{175}$ followed - closely - both Coke and Hawkins on the law relating to brothels (bawdy houses) and the same being a common nuisance. Thus, he noted, under the title 'Lewdness' that:

the offence of keeping a bawdy house cometh also under the cognizance of the law temporal, as a common nuisance, not only in respect of its endangering the public peace, by drawing together dissolute and debauched persons, but also in respect of its apparent tendency to corrupt the manners of both sexes.....And offenders of this kind are punishable not only with fine and imprisonment, but also with such infamous punishment as to the court in discretion shall seem proper. ${ }^{176}$

Burn provided an indictment for keeping a disorderly house, that X:

did keep and maintain, and yet [still] doth keep and maintain, a certain common, ill governed, and disorderly house, and in his said house, for his own lucre and gain, certain evil and ill-disposed persons, as well men as women, of evil name and fame, and of dishonest conversation, to frequent and come together, then, and the said divers and other times, there unlawfully and wilfully did cause and procure; and the said men and women, in his said house, at unlawful times, as well in the night as in the day, then and the said other times, there to be remain, drinking, tipling, whoring, and misbehaving themselves, unlawfully and wilfully did permit, and yet [still] doth permit, to the great damage and common nuisance of all the subjects of our lord king, and against the peace of our said lord the king, his crown and dignity. ${ }^{177}$ (italics supplied)

\section{(b) Blackstone (1765-9)}

Blackstone, in his Commentaries on the Laws of England (1765-9), said very little on disorderly houses. Writing on 'common nuisances', ${ }^{178}$ he stated:

All disorderly inns or ale-houses, bawdy-houses, gaming-houses, stage-plays unlicensed, booths and stages for rope-dancers, mountebanks, and the like, are public nuisances, and may upon indictment be suppressed and fined. ${ }^{179}$

\footnotetext{
${ }^{173}$ Ibid, p 721. The analysis on this in the 1824 edition was more extensive than in the 1716 edition, referring to: (a) keeping, and frequenting, a common gaming house; (b) fraudulent gaming; (c) excessive gaming; (d) the offence of gaming by playing at prohibited games; (d) stock jobbing; and (e) horse racing.

${ }^{174}$ Ibid, p 717. Hawkins stated 'It seems, that a common nuisance may be defined to be an offence against the public, either by doing a thing which tends to the annoyance of all the king's subjects, or by neglecting to do a thing which the common good requires.'

${ }^{175}$ R Burn, Justice of the Peace and Parish Officer ( $1^{\text {st }}$ ed, $1755,23^{\text {rd }}$ ed, $1820,30^{\text {th }}$ ed (last), 1869).

${ }^{176}$ Burn, n 175,(1755 ed), vol 2, p 120. The wording in the $23^{\text {th }}$ ed of Burn (in 1820) is almost the same as this $1^{\text {st }}$ edition of 1755 . Burn also mentioned the right of a constable to enter a house where information was given of persons committing adultery or fornication, without restricting it to London: "And upon information given to a constable, that a man and woman are in adultery or fornication together, or that a man and a woman of evil report have gone to a suspected house together in the night, the officer may take company with him, and if he find them so, he might carry them before a justice, to find sureties of the good behaviour.' (he cited the case of Gylys v Watterkyn (1486), n 117). Burn, p 121, also noted 'Adultery and fornication were anciently inquirable in the torn and leet....And this power doth not seem to have been taken way by any statute'.

${ }^{177}$ Ibid, p 121. Cf West (in 1641), n 130, pt 2, pp 153-4(indictments for keeping a bawdy house, in latin).

${ }^{178}$ Blackstone, n 13, vol 4, p 167 'Common nuisances are a species of offences against the public order and oeconomical regimen of the state; being either the doing of a thing to the annoyance of all the king's subjects, or the neglecting to do a thing which the common good requires.'

${ }^{179}$ Ibid, p 168. He also stated: 'Inns, in particular, being intended for the lodging and receipt of travellers, may be indicted, suppressed, and the inn-keepers fined, if they refuse to entertain a traveller without a very sufficient cause: for thus to frustrate the end of their institution is held to be disorderly behaviour. Thus, too the hospitable laws of Norway punish, in the severest degree, such inn-keepers as refuse to furnish
} 
This statement is accurate, save that it is appropriate to insert the word 'common' in front of all these references. Blackstone also noted the following:

- $\quad$ Adultery \& Fornication. In 1650 (during the Civil War (1649-60)) adultery was made a capital offence. And, keeping a brothel and fornication was made a felony without benefit of clergy (on a second conviction). ${ }^{180}$ However, these offences were not renewed on the restoration of Charles II (1660-85) in $1660 ;^{181}$

- Frequenting Brothels. This was an indictable offence. ${ }^{182}$ Blackstone cited Wheelhouse (1626) ${ }^{183}$ where a man was fined $40 \mathrm{~s}$ for frequenting a suspected brothel (bawdy house). In the case, in which only Doderidge and Whitlock were the only judges, ${ }^{184}$ it was stated that: 'by the common law every man may arrest him who is a noctivagus [nightwalker], and the word (noctivagus) implies that he was a common nightwalker, and they said that justices of the peace by their commission have power to take such indictments, for it is of ill behaviour. " 185

In conclusion, Burn and Blackstone added little to Hawkins on the matter of disorderly houses.

\section{Legal Writers: Russell (1819)}

Russell, in the first edition of his Crimes and Misdemeanors in 1819 - a seminal work which was to last until 1964 - ${ }^{186}$ considered disorderly houses under the generic heading of public nuisances, observing as to the latter that:

Public nuisances may be considered as offences against the public order and economical regimen of the state; being either the doing of a thing to the annoyance of all the king's subjects, or the neglecting to do a thing which the common good requires. ${ }^{187}$ But the annoyance or neglect must be of a real and substantial nature: and the fears of mankind, though they may be reasonable, will not create a nuisance. ${ }^{188}$

In respect of disorderly inns etc., Russell (repeating Blackstone) stated:

All disorderly inns or ale houses, bawdy houses, gaming houses, play-houses, unlicensed or improperly conducted, booths and stages for rope-dancers, mountebanks, and the like, are public nuisances, and may therefore be indicted. ${ }^{189}$

Russell then considered these matters under various headings:

\section{(a) Disorderly Common Inns}

Russell stated:

It seems to be agreed, that the keeper of an inn may, by the common law, be indicted and fined as being guilty of a public nuisance, if he usually harbours thieves, or persons of scandalous reputation, ${ }^{190}$ or

accommodation at a just and reasonable price.' Blackstone cited JO Stiernhook, De Jure Sueonum et Gothorum Vetusto (Holmiae, 1672), Bk 2 c 9. However, as asserted previously, this offence was treated (at least since 1465) as a separate offence and not as an example of a 'disorderly house' as such. See 9(a).

${ }^{180}$ See also T Wood, An Institute of the Laws of England (London, 1772), p 394 'Although adultery and fornication are punishable by the ecclesiastical law, yet the keeping of a house of bawdry, stews, or brothel house, being as it were a common nuisance, is punishable by the common law upon an indictment, by fine and imprisonment. And those, that are vehemently suspected of resorting to houses of bawdry, may be bound to their good behaviour, as well as common whoremongers and common whores. For adultery and fornication are offences temporal as well as spiritual, being offences prejudicial to mens bodies and estates, as well as to their souls, and highly destructive of the public government.' See also Burford, n 49, p 179.

${ }^{181}$ Blackstone, $\mathrm{n}$ 13, vol 4, p 64. Blackstone also noted, pp 64-5, 'The temporal courts...take no cognizance of the crime of adultery, otherwise than as a private injury.' Ibid, vol 3, p 139 'Adultery, or criminal conversation with a man's wife, though it is, as a public crime, left by our laws to the coercion of the spiritual courts; yet, considered as a civil injury...the law gives a satisfaction to the husband for it by an action of trespass vi et armis against the adulterer, wherein the damages recovered are usually very large and exemplary.'

${ }^{182}$ Ibid, p 64 'offence... of open and notorious lewdness...by frequenting houses of ill-fame [ie brothels]...is an indictable offence.'

${ }^{183}$ Popham 208 (79 ER 1297). Cited as Willow's Case in Latch 173 (82 ER 331). Jacob, n 156, p 278 (citing this case) 'If a man be indicted for frequenting a bawdy house, it must appear that he knew it to be such a house; and it must be expressly alleged in the indictment that 'tis a bawdy house, and not by suspicion only.'

${ }^{184}$ Sir John Doddridge was a judge of the Queen's Bench from 1612-28 and Sir James Whitelocke from 1624-32. See Sainty, n 143 , p 31.

${ }^{185}$ For a case in 1497 , see $\mathrm{n} 142$.

${ }^{186}$ The last edition was edited by JWC Turner. It may be noted that EH East, A Treatise of the Pleas of the Crown (1803) did not deal with disorderly houses.

${ }^{187}$ Russell, n 14, vol 1, p 428. Russell cited Blackstone, see n 178.

${ }^{188}$ Ibid. Russell cited Anon, see n 164.

${ }^{189}$ Russell, n 14, vol 1, p 431. See also Blackstone, n 179.

${ }^{190}$ Cf. 6. 
suffer frequent disorders in his house, or take exorbitant prices, or set up a new inn in a place where there is no manner of need of one, to the hindrance of other ancient and well governed inns, or keep it in a place in respect of its situation wholly unfit for such a purpose. ${ }^{191}$

\section{(b) Bawdy Houses, Common Gaming Houses \& Common Cockpits}

Russell stated:

It is clearly agreed that keeping a bawdy-house is a common nuisance, as it endangers the public peace by drawing together dissolute and debauched persons; and also has an apparent tendency to corrupt the manners of both sexes, by such an open profession of lewdness ${ }^{192} \ldots$. But an indictment cannot be maintained against a person for being a common bawd, and procuring men and women to meet together to commit fornication: the indictment should be for keeping a bawdy-house. For the bare solicitation of chastity is not indictable, but cognizable only in the ecclesiastical courts... ${ }^{193}$ all common gaming-houses ${ }^{194}$ are nuisances in the eye of the law, being detrimental to the public, as they promote cheating and other corrupt practices; and incite to idleness, and avaricious ways of gaining property, great numbers whose time might otherwise be employed for the good of the community... There are also certain penalties imposed by statutes upon the offence of keeping a common gaming house...

Russell also noted that:

An indictment against a defendant for that he did keep a common, ill governed, and disorderly house, and in the said house for his lucre, etc certain persons of ill name etc to frequent and come together, did cause and procure, and the said persons in the said house to remain fighting of cocks, boxing, playing at cudgels, and misbehaving themselves, did permit, has been held to be good. ${ }^{195}$

\section{(c) Play Houses}

\section{Russell stated:}

It seems to be the better opinion that playhouses, having been originally instituted with a laudable design of recommending virtue to the imitation of the people, and exposing vice and folly, are not nuisances in their own nature, but may only become such by accident; as, where they draw together such numbers of coaches or people etc as prove generally inconvenient to the places adjacent; or, when they pervert their original institution by recommending vicious and loose characters, under beautiful colours, to the imitation of the people, and make a jest of things commendable, serious and useful. Players and

\footnotetext{
191 Russell also noted that it was a common law offence for a common innkeeper to refuse to provide board and lodging to traveller. It is asserted this offence is obsolete, see $\mathbf{9 ( a )}$.

192 Ibid, p 432. Also, 'If a person be only a lodger, and have but a single room, yet if she make use of it to accommodate people in the way of a bawdy-house, it will be a keeping of a bawdy-house as much as if she had a whole house.' The citation was to $R v$ Pierson (1706) 2 Ld Raym 1197 (92 ER 291) and 1 Salk 382 (91 ER 333). In this case the court held an indictment cannot be maintained against anyone for being a 'bawd' and procuring ill-disposed persons to meet and commit fornication. Thus, the judgment of being a bawd was reversed since the indictment ought to have been that of keeping a common bawdy house. At p 1197 'what is charged in this indictment is but a solicitation of chastity, which is a spiritual offence, and not inquirable or punishable at common law.' In 1 Salk the indictment is stated as being that the defendant 'fuit communis lena ac male dispositas personas in domibus lupanaribus convenire \& scortationes \& fornicationes committere pro suo lucro proprio 'illicite procuravit' ('he was a common bawd and he unlawfully procured ill-disposed persons to meet in bawdy houses and to commit whoredom and fornications there, for his own profit.'). The court is also stated as saying 'if a lodger, who has only a single room, will therewith accommodate lewd people to perpetrate acts of uncleanness, she may be indicated for keeping a bawdy-house; but a bare solicitation of chastity is not indictable.' Cf. Galizard v Rigault (1702) 2 Salk 552 (91 ER 467)(prohibition to a suit brought for solicitation of chastity) per Holt CJ 'no indictment lies at common law for adultery.' Coke, n 10, vol 4, p 21 'In ancient time the kings courts, and specially the leets had power to enquire of, and punish fornication and adultery by the name of letherwite, and it appeareth often in the book of Domesday that the king had the fines assessed for those offences which were assessed in the kings courts, and could not be inflicted in curia christianitatis [in the ecclesiastical courts].

${ }^{193}$ Ibid, pp 432-3. The first edition of Archbold in 1822 (see n 15) contains an indictment for keeping a keeping a bawdy house, see $\mathrm{p} 362$. The indictment describes it as a 'common ill-governed and disorderly house' in which persons remained for 'drinking, tippling, whoring, and misbehaving themselves' which house was a 'common nuisance'. The form of this indictment is a slight adaptation to that of Burn in 1755 , see n 177.

194 The reference to 'common gaming house' derived from the Act of 1541, see n 163. For an indictment in Archbold (in 1822) for maintaining a common gaming house where 'idle and evil disposed persons' come to play a 'certain unlawful game at cards' which is a 'common nuisance' see Archbold, n 15 (1822 ed), p 363.

${ }^{195}$ Russell referred to Higginson, see 9(e). Russell added 'And it seems that the keeping of a cockpit is not only an indictable offence at common law, but that a cockpit is considered as a gaming house within the statute 39 Hen VIII c $9 \mathrm{~s} \mathrm{11(see} \mathrm{n} \mathrm{168)} \mathrm{which} \mathrm{imposes} \mathrm{a} \mathrm{penalty} \mathrm{of}$ forty shillings per day upon such houses; and therefore, on a conviction on an indictment at common law, the court will measure the fine by inflicting forty shillings for each day, according to the number of days such cockpit was kept open.' He referred to Howel, see n 165 .
} 
playhouses are now put under salutary regulations by the provisions of several statutes... ${ }^{196}$ It also seems to be the better opinion, that all common stages for rope dancers etc are nuisances, not only because they are a great temptation to idleness, but also because they are apt to draw together numbers of disorderly persons, which cannot but be very inconvenient to the neighbourhood. ${ }^{197}$

In conclusion, Russell In 1819) - similar to Hawkins (the last edition of which was in 1824) - considered, under the concept of 'disorderly houses': (a) disorderly common inns; (b) brothels; (c) common gaming houses; (d) common houses where cockfighting occurred; (e) playhouses; and (f) common stages for rope dancers.

\section{Gabbett (1843), Paterson (1877), Harris (1881) \& Stephen (1883)}

In respect of legal writers in the $19^{\text {th }}$ century who published after Russell (see 11), it is noticeable how little they wrote on the offence of keeping a disorderly house.

\section{(a) Gabbett (1843)}

Joseph Gabbett, in his Treatise on Criminal Law in 1843, had a chapter 'Of Disorderly Houses - Keeping'. ${ }^{198}$ On bawdy houses (brothels) he stated:

Though fornication is an offence which, in modern times, is left to the coercion of the spiritual court, yet the keeping a bawdy-house or brothel-house is indictable as a public [common] nuisance, or offence against the public order and economical regimen of the state... ${ }^{199}$ An indictment for keeping a common bawdy-house (or gaming house) may...be general, without charging any particular fact of disorderly conduct in it; and the only certainty required in the indictment is to state the place where the house is situate, and the time when the offence of keeping it was committed; for, as the offence is the keeping of the house, the party is thereby sufficiently appraised of the nature of the charge which is intended to be proved against him. ${ }^{200}$

Gabbett also dealt with: common gaming houses, ${ }^{201}$ common playhouses ${ }^{202}$ and a common stage for rope dancers. $^{203}$ Finally, he cited Blackstone and Hawkins:

According to Sir W Blackstone, all disorderly inns or alehouses are public nuisances, as well as bawdy houses, gaming houses, stageplays, unlicensed booths, and stages for rope dancers, mountebanks, and the like; and may, upon indictment, be suppressed. And Sarjeant Hawkins also lays it down, that the keeper of an inn may, by the common law, be indicted and fined as being guilty of a public nuisance, if it usually harbor thieves or persons of scandalous reputation, or suffer frequent disorders in his house etc. ${ }^{204}$

For his part, Paterson - in his Commentaries on the Liberty of the Subject (1877) - said virtually nothing on disorderly houses, apart from referring to ancient punishments ${ }^{205}$ and noting that it was an indictable offence to

\footnotetext{
${ }^{196}$ In particular, Russell referred to 25 Geo II c 36 (1751, rep). See 9(d).

${ }^{197}$ Russell, n 14, vol 1, pp 435-6. He referred to Bacon, n 26, vol 5, title 'Nuisances' pp 146-7 (it contains a useful summary in 1798).

198 J Gabbett, Treatise on the Criminal Law (Dublin, 1843), ch 18, pp 289-93.

199 At $\mathrm{p} 289$.

${ }^{200}$ Reference was made to J'Anson $v$ Stuart (1787) 1 TR 748, 754 per Buller J 'with respect to the case of an indictment for keeping a common bawdy-house... it must state the place where the house is situate and the time... it is not necessary to prove who frequents the house, for that may be impossible; but if any unknown persons are proved to be there behaving disorderly, it is sufficient to support the indictment.'

${ }^{201}$ At p 290 'All common gaming-houses are also nuisances in the eye of the law, being detrimental to the public, as they promote cheating and other corrupt practices, and incite great numbers to idleness and avaricious ways of gaining property, whose time might otherwise be employed for the good of the community.' Also, 'But it seems that play-houses, being originally instituted with the laudable design of commending virtue to the imitation of the people, and exposing vice and folly; are not nuisances in their own nature, but may become such by accident; as where they are productive of public inconvenience in the manner above mentioned.'

${ }^{202}$ Ibid, pp 291-2. Gabbett noted 'It hath also been holden that a common play-house may be a nuisance, if it draw together such a number of coaches or people, etc as prove generally inconvenient to the places adjacent'. He referred to $R v$ Betterton et al (1695) 5 Mod 142 (87 ER 571), Holt 538 (90 ER 1196) and Skinner 625 (190 ER 281) (if a licensed playhouse from the great concourse of people resorting to it, became a nuisance, whether the Court of King's Bench could grant a prohibitory writ to suppress it or whether it must be left to the common mode of prosecution by indictment).

${ }^{203}$ Ibid, p 292 'A play-house is thus distinguishable from a common stage for rope-dancers, which is a nuisance per se, not only because such exhibitions are a great temptation to idleness, but because they are apt to draw together great numbers of disorderly persons, which cannot but be very inconvenient to the neighbourhood.'

${ }^{204}$ Ibid. For Blackstone see n 179. For Hawkins, see n 148.

205 J Paterson, Commentaries on the Liberty of the Subject (Macmillan \& Co, 1877), vol 2, pp 392-3, 'The keepers of disorderly houses for prostitution have usually been selected for some kind of punishment. The Mosaic laws imposed scourging as the punishment for this offence. The Greeks in some places caused procuresses to be tied in a sack and thrown into the sea. The Roman law subjected procuresses to banishment, and sometimes to death...Among the early Christians the procurers of prostitution were dealt with as severely as in the case of adultery and
} 
keep a brothel. ${ }^{206}$ Finally, Harris - in his Principles of the Criminal Law in 1881 - stated:

The following places are nuisances, and, upon indictment, may be suppressed, and their owners, keepers, or ostensible managers punished by fine or imprisonment, or both - disorderly inns ${ }^{207}$ or alehouses; bawdy houses; gaming and betting houses; unlicensed or improperly conducted playhouses, booths, stages for dancers, and the like. ${ }^{208}$

\section{(b) Stephen (1883)}

Sir James Fitzjames Stephen, in his Digest of the Criminal Law in $1883,{ }^{209}$ proposed a statutory formulation for keeping a disorderly house (article 178) as follows:

Every one who keeps a disorderly house commits a common nuisance, and is liable upon conviction thereof to be sentenced to hard labour. Any person who appears, acts, or behaves as master or mistress, or as the person having the care, government, or management of any disorderly house, is to be deemed and taken to be the keeper thereof, and is liable to be prosecuted and punished as such, although, in fact, he is not the real owner or keeper thereof. ${ }^{210}$ But the owner of a house, conducted as a disorderly house by a person to whom he lets it as a weekly tenant, is not the keeper of the house merely because he knows the use to which it is put, and does not give his tenant notice to quit. ${ }^{211}$

Stephen then defined disorderly houses to comprise:

(a) common bawdy houses; ${ }^{212}$

(b) common gaming houses;

(c) common betting houses; and

(d) disorderly places of entertainment, ${ }^{213}$ which covered theatres, dance halls and meeting halls. ${ }^{214}$

Separate provision was made for disorderly inns. ${ }^{215}$ Today, Stephen's definition is of little assistance since (a)-(d) are, today, regulated by distinct legislation. Further, many of his definitions are exceedingly wide.

\section{(c) Prostitutes \& Persons of Notoriously Bad Character}

In 6, it was noted it was likely that common inns and taverns 'haunted' by persons of ill fame were held to be 'disorderly houses' in medieval times. This matter was not traced through the ensuing centuries since - by 1839 what remained of this concept was contained in the Metropolitan Police Act 1839 which applied to the Metropolitan Police District of London ('MPD') which comprised 'Greater' London and not the City of London. Of the extant sections of this Act, section 244 provides that every person who shall have or keep 'any house, shop, room, or place of public resort' in the MPD where 'provisions, liquors, or refreshments of any kind shall be sold or

subjected to capital punishment by drowning in a sack or burning alive. Theodosius destroyed all infamous houses in Rome, and Theodosius Junior at Constantinople did the same and ordered panders to be publicly whipped and expelled the city.'

${ }^{206}$ Ibid, p 393.

${ }^{207}$ A footnote notes 'If a traveller is refused entertainment without sufficient cause, the inn is liable to be treated as a disorderly inn.' However, it is asserted this is a separate offence. See 9(a).

${ }^{208}$ SF Harris, Principles of the Criminal Law (Stevens \& Haynes, 1881, $2^{\text {nd }}$ ed), p 136. As to lotteries he noted 'All lotteries were declared by statute public nuisances. State lotteries were, however, authorized by successive Acts of Parliament until 1824, when they were discontinued, the State being thus enabled without inconsistency to enforce the already existing law against other lotteries.'

209 JF Stephen, A Digest of the Criminal Law (Macmillan \& Co, $3^{\text {rd }}$ ed, 1883). JF Stephen, A History of the Criminal Law of England (Macmillan \& Co, 1883) does not deal with disorderly houses.

${ }^{210}$ He referred to the Disorderly Houses Act 1751 and 21 Geo 3 c 49 s 2 (1780, Sunday Observance, rep). See 9(d).

${ }^{211}$ Stephen, $\mathrm{n} 209$, pp 121-2. He defined disorderly houses (art 179) as follows: 'The following are disorderly houses, that is to say, common bawdy houses, common gaming houses, common betting houses, disorderly places of entertainment.'

${ }^{212}$ Ibid, p 122 (Article 180) 'A common bawdy house is a house or room, or set of rooms, in any house kept for the purposes of prostitution. And it is immaterial whether indecent or disorderly conduct is or is not perceptible from the outside.'

${ }^{213}$ Ibid, p 122 (Article 179).

${ }^{214}$ Ibid (Article 184) 'The following are disorderly places of entertainment, that is to say - (a) Every house, room, garden, or other place kept for public dancing, music, or other public entertainment of the like kind in the cities of London and Westminster, or within twenty miles thereof, without a licence granted in compliance with the provisions of 25 Geo 2, c 36 [ie. Disorderly Houses Act 1751]...(b) Every house, room, or other place opened or used for public entertainment or amusement, or for publicly debating on any subject whatsoever upon any part of the Lord's Day, called Sunday, and to which persons are admitted by the payment of money, or by tickets sold for money.'

${ }^{215}$ Ibid (Article 185) 'A disorderly inn is an inn kept in a disorderly manner and suffered to be resorted to by persons of bad character for any improper purpose. Every person who keeps a disorderly inn, or who, being an innkeeper, refuses, without reasonable grounds, to entertain any person ready and willing to pay for entertainment there, commits a misdemeanor.' 
consumed' who shall

wilfully or knowingly permit drunkenness or other disorderly conduct in such house, shop, room, or place ... or knowingly permit or suffer prostitutes of notoriously bad character to meet together and remain there...(italics supplied)

is liable to a fine. ${ }^{216}$ This section would cover any common inn or common tavern. It has been asserted this section should be repealed - not least since similar provisions with respect to the City of London as well as urban districts have been repealed. ${ }^{217} \mathrm{Be}$ that as it may, this - and any application of the offence of keeping a 'disorderly house' to the extent that it purports to apply to persons of 'ill fame', 'thieves and other criminals', persons of 'notoriously bad character' etc. - militates against the intent of the Rehabilitation of Offenders Act 1974 as well as create an offence that is wholly subjective and too uncertain in ambit to be sustainable in modern times. ${ }^{218}$

In conclusion, after Russell, legal writers said little on the offence of keeping a disorderly house. However (following Hawkins) they now used 'disorderly house' to cover not just bawdy houses and common inns - but also common gaming houses, common betting houses, common rope dancing places, common cockpits and places of entertainment in London (for the latter, see Disorderly Houses Act 1751). Thus 'disorderly house' had become a generic term. That said, including within this concept of 'disorderly house' a common inn or tavern which permitted thieves, prostitutes etc. to 'haunt'its premises would seem no longer possible after 1839 since legislation provided for the matter (which legislation is, it is asserted, also obsolete). ${ }^{219}$

\section{Offence Prior to Berg in 1927}

Because of its long legal history of the offence of keeping a 'disorderly house' - as with other common law and 'longtime' statutory offences (such as treason) ${ }^{220}$ - uncertainties about the nature of this offence have arisen. In particular,

- The key to all prior forms of 'disorderly house' was that they were 'common'. That is, the 'house' was open to the public in some way. Thus, common bawdy house, common inn, common gaming house etc. However, this point was often missed in legal writings, although not in the wording of the indictment; ${ }^{221}$

- The offence of keeping a 'disorderly house' also had to be for money ('lucre and profit'), a point also often missed by legal writers, although not in the wording of the indictment; ${ }^{222}$

- Private conduct - such as adultery and fornication not in a 'common' house - was only punishable as a London custom where persons committing adultery and fornication in a house in the City of London could be arrested, fined and required to provide surety for their good behaviour. However, by 1486 (see $\mathbf{5 ( a ) )}$, there was uncertainty about the reasonableness of this custom and, after that time, it was treated as an ecclesiastical, and not a criminal, offence (apart from a limited period during the Civil War, 1649-60).

Unfortunately, these points were missed in the case of Berg which is now considered.

\section{Berg (1927)}

This case is very poorly reported since the facts - as well as the precise nature of the acts complained of - were left unclear in the report of the case before the Court of Criminal Appeal. ${ }^{223}$ However, certain of the facts appear to be as follows:

\footnotetext{
${ }^{216}$ A similar provision in the Town Police Clauses Act 1847, s 35 was repealed in 2003. See also Prevention of Crimes Act 1871 (rep), s 10. It imposed penalties on keepers of lodging houses, places of public entertainment or places licensed for the sale of intoxicants who knowingly lodged or harboured thieves (or reputed thieves) or knowingly suffered their meeting in the house or the deposit therein of goods which they had reason to believe had been stolen.

217 Ibid.

218 Ibid.

219 Ibid.

${ }^{220}$ Treason is a good example of a longtime statute (the Treason Act 1351) becoming warped through constant judicial analysis, resulting in many constructive treasons out of kilter with the true nature of the offence. See McBain, $\mathrm{n} 81$.

${ }^{221}$ See Higginson (1762), n 163 ('common ill governed and disorderly house'), Rogier \& Humphrey (1823), n 236 ('a certain common gaming house') and $R v$ Rice and Wilson (1866), $\mathrm{n} 258$ ('a certain common ill governed and disorderly house'). See also Burn (1755), n 177.

${ }^{222}$ Ibid.

223 (1927) 20 Cr App R 38.
} 
- One Brett owned a house in London (25 Fitzroy Square which is not in the City of London) ${ }^{224}$ in which he lived with his female partner, Carre. The house was visited from time to time by Britt's nephew, Lummies. Also, one Berg visited the house but did not live there; ${ }^{225}$

- All four were were convicted of a common law conspiracy to corrupt the morals of, and to debauch, persons resorting to a certain disorderly house. ${ }^{226}$ Britt and Carrie were also convicted of keeping a disorderly house and Lummies of aiding and abetting them. ${ }^{227}$ However, there is no evidence of how persistent was the 'disorderliness' - an important element in respect of the keeping of a disorderly house;

- It was also left unclear whether any payment was made for the sexual services. This is another important element in respect of the keeping of a disorderly house, since it must be for 'lucre or gain'; as in the case of bawdy houses, gaming houses, cockpit fighting etc.; 228

- It is also unclear what the sexual services were. It seems the charge was that persons were visiting (or might visit) the house to engage in homosexual acts with Britt. ${ }^{229}$ However, who were these people being debauched ? It cannot be any of the four appellants since they were convicted of conspiring to debauch. Yet the case cites no member of the public or other person who ever visited the house. This is important in respect of the offence of keeping a disorderly house where an element of 'open house' is required. That is, it must be a 'common' house - one open to the public in some fashion;

- The indictment was formulated on the basis of Higginson (1762), an indictment for keeping a disorderly house (common cockpit); ${ }^{230}$

- At their trial, rather extraordinarily, the Recorder based his definition of a 'disorderly house' not on any case or legal texts, but on Webster's dictionary - even though the prosecution had not proferred the same. ${ }^{231}$

Avory J (who gave judgment) ${ }^{232}$ noted that the gist of the indictment was that the accused were:

lewd and immoral persons assembled for the purpose of unnatural practices. ${ }^{233}$

What these practices were is unclear; however, this expression (in 1927) likely referred to homosexual practices. ${ }^{234}$ As to the offence of keeping a 'disorderly house', the judicial analysis was poor although the court can hardly be blamed since counsel failed to provide any analysis of the history of the offence nor indicate, with precision, various elements requisite for it.

(a) Cockpits etc. Avory J noted that an indictment for keeping a disorderly house for cock fighting,

\footnotetext{
${ }^{224}$ Fitzroy Square is W1T 6 EU. By 1927, the City of London was limited to the Square Mile. Fitzroy Square is part of Greater London. This is important since no London custom re adultery or fornication would have applied (see 5), even if the same were not otherwise obsolete.

${ }^{225}$ The case report says that he was 'free' of the house.

${ }^{226}$ This was the main charge, the 'disorderly house' charge being secondary. In Shaw v DPP [1962] AC 220 at $\mathrm{p} 288$ Lord Tucker noted that the indictment in Berg stated that the accused 'conspired together and with persons unknown to debauch and corrupt the minds and morals of such persons as should be induced or permitted to come to certain premises, being [25 Fitzroy Square] and their remain tippling whoring and behaving in an obscene and disorderly manner.' Lord Tucker also noted the case report was inaccurate on the description in the conspiracy count. As it is, it is asserted that no charge should have been brought on the basis of a 'disorderly house.' For a case where a conspiracy account alone was brought (successfully) see $R v$ Dale (1960) (unreported) referred to by Lord Tucker.

${ }^{227}$ Britt received imprisonment for 15 months with hard labour, Lummies received 8 months in prison, Berg received 6 months in prison and Carre was bound over.

${ }^{228}$ See $\mathrm{n} 221$.

${ }^{229}$ Various letters appear to have been addressed to Britt referring to unnatural acts, see p 41 and Avory J, p 42, referred to 'unnatural practices' In Tan (see 15), Parker J at p 1060 stated 'The facts of the case [ie. Berg] are not set out in the report but it may be inferred that the accused and others took part in exhibitions of a perverted nature for the edification of those resorting to the premises'. However, this is something of a guess. The case notes that the police found letters in the house addressed to Britt which referred to unnatural practices. The police also took photos of the accused whom they requested to pose as dancers or actors dressed up for their parts (this observation in the case may have been an oblique hint that the men were dressing as women). Although the court indicated that these letters and photos were not evidence, it is likely they were prejudicial to the defendants at first instance.

${ }^{230}$ See $n 163$.

${ }^{231}$ At $\mathrm{p} 41$. The definition of Webster was 'not regulated by the restraint of morality; unchaste; of bad repute, as a disorderly house.' See also $\mathrm{p}$ 40 .

${ }^{232}$ The judges on appeal were Avory J, Shearman J and Sankey J.

${ }^{233}$ At $\mathrm{p} 42$.

${ }^{234}$ See n 229.
} 
boxing etc. was held good, citing Higginson (1762). ${ }^{235}$ However, this was of scant relevance to the instant case since the accused were not indicted for keeping a common cockpit;

(b) Not a 'Common' House. Avory J dismissed an argument that - unless a house was open to the public at large - it was not indictable as a disorderly house as being refuted by Rogier \& Humphrey (1823) ${ }^{236}$ and Jenks $v$ Turpin (1884) although he also noted that these cases concerned gaming houses (which were regulated by statutory provisions in the main);

(c) Public Mischief. Avory J stated 'It is a well ascertained principle of the common law that acts involving public mischief are indictable misdemeanours, ${ }^{237}$ Further, he referred to Stephen who in his Digest (article 265) stated that a 'disorderly inn is an inn kept in a disorderly manner, and suffered to be resorted to by persons of bad character for any purpose. ${ }^{238}$ However, these observations are not of relevance since the appellants were not indicted for public mischief and their house was not a common inn. Further, the citation to Stephen was not to a judgment but to Stephen's Digest his declaration of what, he hoped, might become the law. In fact, his Digest did not become law - whether in whole or part; ${ }^{239}$

(d) Common Law Expandable. Finally, Avory J cited an observation of Parke B from certain Parliamentary Papers of 1854 that 'the rules of the common law have the incalculable advantage of being capable of application to new combinations of circumstances perpetually occuring' ${ }^{240}$ However, this was not a judicial statement of Parke B and it was of scant relevance to the instant case;

(e) Recorder's Definition. Avory J stated as to the Recorder's definition 'The Recorder's definition from Webster is somewhat vague, but would be correct if the element of keeping open house is present and there is added 'being so conducted as to violate law and good order;' ${ }^{241}$ Thus, it seems that Avory J was seeking to distinguish between a house 'open to the public at large' and an 'open house'. However, the prior history of this offence does not suggest such a subtle distinction; ${ }^{242}$

(f) Regularity. For the offence, there must be evidence of persistent behaviour. However, there seems to have been none proved in the case, ${ }^{243}$

(g) Open House. For his part, Shearman J noted that the instant case was not like Saunders v Hitchcock $(1875)^{244}$ where the public were admitted (by payment only) to see an indecent exhibition in a booth on a

\footnotetext{
${ }^{235}$ At $\mathrm{p} 41$. However, as counsel for one of the defendants pointed out, nothing in that case was mentioned but 'fighting of cocks, boxing, playing at cudgels and misbehaving themselves.' That is, it dealt with games, not sexual matters.

${ }^{236} 1$ B \& C 272 (107 ER 102) \& 2 D \& R 431. The indictment stated, inter alia, that 'they unlawfully did keep and maintain a certain common gaming house; and in the said common gaming house, for lucre and gain, unlawfully and wilfully did cause and procure divers evil disposed persons to frequent and come to play together, at a certain unlawful game at cards, called 'rouge et noir'. Hawkins J in Jenks $v$ Turpin (1884)13 QBD 505 (a case concerning unlawful gambling under the Gaming Houses Act 1854, rep), p 515 noted that 'Best J said [in Rogier] 'Any practice which has a tendency to injure the public morals is a common law offence' and both he and Abbott CJ treated playing at innocent games for excessive amounts as illegal.' Hawkins J, at p 505, also stated 'In my judgment, the keeping of a common gaming-house is in itself a nuisance, and the keeper of it is as such guilty of an indictable offence.'

${ }^{237}$ At $\mathrm{p} 41$.

${ }^{238}$ See $\mathrm{n} 215$

${ }^{239}$ It would have been, perhaps, more apposite for Avory J to have referred to the Metropolitan Police Act 1839 in respect of bad character, see 12(c).

${ }^{240}$ At $\mathrm{p}$ 41. This comprised Parliamentary Papers of 1854 (copies of the Lord Chancellor's letters to the judges and their answers) with the observation of Parke B being cited by Finlay A-G in Brailsford (1915) 2 KB at 730 at 739.

${ }^{241}$ Ibid.

${ }^{242}$ In Brady and Ram (see n 259), Parker CJ stated: 'The case [Berg] provides clear authority that (a) there must be some element of keeping open house albeit the premises need not be open to the public at large, (b) the house must not be regulated by the restraints of morality or must be unchaste or of bad repute and (c) that it must be so conducted as to violate law and good order.' As to (a) this would not seem correct. The history indicates that the house can be a private house, but it still must be accessible to the public in some way (by their being invited in; it must be a 'common' house). As to (b) and (c) this is, with respect, just verbiage and far too wide in extent. What does 'unchaste' mean ? What does 'bad repute' (ill fame) mean in a modern context? It would have been preferable to have connected the activities to other common law offences - such as outraging public decency etc. Otherwise, the offence of keeping a disorderly house simply becomes that of keeping a house in which sexual conduct is carried on, which conduct is disapproved of by the judge hearing the case.

${ }^{243}$ Shearman J referred to Harrison 8 NSW LR 57 (1887) 'On an indictment [at common law] for keeping a brothel, it may be sufficient in the circumstances of the case to prove what took place on one night only, It is not necessary to prove that the accused actually received any gain or profit per the Supreme Court.' However, while this might have been the position re brothels in New South Wales, the offence of keeping a disorderly house under English law did require persistence. See Moores v DPP (1992) (see 16) which, effectively, overrules Berg on this point.

244 (1875) 13 Cox CC 116. It was held that a booth (tent) on a racecourse to which persons were admitted by payment was a public place so as to support an indictment for an indecent exhibition. The accused were convicted on 8 counts (one of which was later dropped) and appealed. The booth was at Epsom races and contained 25 persons who paid money to see a husband and wife undertaking sexual acts (not described in
} 
racecourse. One would agree, since that case did not concern disorderly houses.

It is clear the court in Berg laboured to sustain the offence of keeping a 'disorderly house' since:

- Keeping a disorderly house is a common nuisance. Thus, there should have been some element of nuisance to the public, such as to neighbours etc. ${ }^{245}$ However, none was referred to;

- The house also had to be a 'common' house - one to which members of the public had access - such as a common bawdy house, common gaming house, cockpit etc. However, there was no evidence produced of any member of the public visiting it. Regrettably, Marks $v$ Benjamin (1839) was also not cited to the court ('it must be public, to which all persons have a right to go.'), ${ }^{246}$ - There should have been evidence of persistent (habitual) disorderly conduct. However, there was none;

- There should have been evidence of services being provided for money or gain ('lucre'). However, there was none;

- In effect then, Britt and the others were convicted for conspiring (but not committing) to debauch (ie. commit homosexual fornication) with others (not named) in a private house. ${ }^{248}$ However, ever since Coke (in 1628), it had been accepted that any 'London' custom re adultery and fornication as criminal offences no longer prevailed.

Thus, it asserted that Berg was misconceived and it cannot be taken as a good precedent vis-à-vis the concept of keeping a disorderly house. ${ }^{249}$ In any case, today, consensual homosexual acts would not be a crime, per se.

- As to legal writers post 1927, Kenny in his Outlines of Criminal Law (1929), ${ }^{250}$ did not deal with the offence of keeping a disorderly house and Harris - in the 1950 edition of his Principles and Practice of the Criminal Law (1950) - said very little on it; ${ }^{251}$

- Turner, in the final edition of Kenny in 1966, as well as Smith and Hogan - in the first edition of their text on Criminal Law in $1965^{252}$ - also did not deal with this offence;

- $\quad$ A useful text, however, is the last edition of Russell, On Crime, edited by Turner in 1966. It summarised the state of the law on disorderly houses by 1966, under the headings of: (a) inns, public houses and refreshment houses; ${ }^{253}$ (b) cockfights; (c) theatres; (d) unlicensed public entertainments; (e) bawdy

\footnotetext{
the case on appeal). The persons who kept the booth were prosecuted for the misdemeanour of outraging public decency and behaviour being injurious to public morality. The case is not relevant to that of a disorderly house since the indictment contained no count as to the same.

${ }^{245}$ No one cited Coke, $\mathrm{n} 92$, 'keeping of a house of bawdry...being as it were a common nuisance.' Nor Blackstone, $\mathrm{n} 179$ 'All disorderly inns etc....are public nuisances'. Nor Russell, $\mathrm{n} 189$. Nor the text to Stephen, n 211, 'Every one who keeps a disorderly house commits a common nuisance...'

${ }^{246}$ See $\mathrm{n} 261$. What should also be noted is that how badly out of kilter this case is with JP's decisions on keeping a 'disorderly house. The British Newspaper Archive (www.britishnewspaperarchive.co.uk) is now online. It covers 261 local newspapers from 1700 with wordsearch. Typing in the words ' disorderly house' reveals a large number of local decisions by magistrates in which they convicted for 'keeping a disorderly house'. At least $95 \%$ relate to brothels. Further, it seems clear that the police gathered evidence of a number of men visiting the premises, on a regular basis. Berg, therefore, is out of kilter with these. The truth of the matter is that the police in Berg brought a case with insufficient evidence.

${ }^{247}$ Ibid, 'habitual keeping of it'.

${ }^{248}$ Homosexuality was a crime in 1927. However, it seems clear that the police (despite their search for letters and taking photos) did not have enough evidence for the same.

${ }^{249}$ Indeed, the observations of Avory J simply confuse things, disclosing a paucity of real analysis.

${ }^{250}$ CS Kenny, Outlines of Criminal Law (Cambridge UP, $13^{\text {th }}$ ed, 1929). The first edition of this work was in 1902. Vincent's Police Code and General Manual of the Criminal Law $\left(16^{\text {th }}\right.$ ed, 1924) noted that 'Disorderly houses are common bawdy houses, brothels, gaming houses, betting houses, and disorderly places of entertainment.'

${ }^{251}$ Harris, $\mathrm{n} 208$ (18 ${ }^{\text {th }}$ ed, 1950), p 214 'Every person is guilty of a common law nuisance who keeps a disorderly house, that expression includes brothels, common gaming and betting houses, and any house which a jury finds to be open to and frequented by persons who so conduct themselves there as to violate law and good order.' R Cross \& PA Jones, An Introduction to Criminal Law (Butterworth \& Co, 1949) did not deal with disorderly houses, although it did consider gaming and betting houses (the latter dealt with by the Betting Act 1853), see pp 278-9.

252 JC Smith \& B Hogan, Criminal Law (London, Butterworths, 1965).

${ }^{253}$ Turner, $\mathrm{n} 18$, vol $2 \mathrm{p} 1434$ 'The keeper of an inn at common law is indictable for public nuisance if he usually harbours thieves or persons of scandalous reputation or suffers frequent disorders in his house'. However, he only cited Prevention of Crimes Act 1871 (rep), see n 216.

Russell also mentioned the offence of a common innkeeper refusing to provide board and lodging which, it is asserted, is a separate offence, see 9(a).
} 
houses; (f) gaming and betting. None of (a)-(d) or (f) is discussed here since it is historic (being a discussion of repealed legislation, such as the Disorderly Houses Act 1751).

- In respect of 'bawdy houses', Turner noted: 'A brothel or common bawdy house is a form of disorderly house, the keeping whereof is a public nuisance... The offence is within the Sexual Offences Act 1956, s 33.' It is a pity that this statement was not considered by prosecutors prior to bringing the cases of Tan (1983) (see 15) and Court and Gu (2012) (see 19).

Mention may also be made of two other reported cases:

- Quinn \& Bloom (1962). ${ }^{254}$ Certain club premises were used for striptease acts and the proprietors of the clubs were convicted of keeping a disorderly house. The court noted that - while a disorderly house might, in some instances, amount to a common nuisance - this element was not an essential ingredient of keeping a disorderly house. No authority was cited for this proposition ${ }^{255}$ and it seems to be clearly incorrect, since keeping a disorderly house is a common nuisance (ie. the rationale for punishing the keeper of it). The court also held that - in respect of cases in which indecent performances or exhibitions were alleged a disorderly house was a house conducted contrary to law and order in that matters were performed (or exhibited) of such a character that their performance (or exhibition) in a place of common resort:

(a) amounted to an outrage of public decency; or

(b) tended to corrupt or deprave; or

(c) was otherwise calculated to injure the public interest, o call for condemnation and punishment.

Further, that the alternatives expressed in (a), (b) and (c) were not to be regarded as mutually exclusive. However, it should be noted that this definition is wholly novel vis-à-vis a disorderly house. ${ }^{256}$ Also, such a definition was heavily influenced by the case of Shaw $v$ DPP (1962) ${ }^{257}$ - although that case did not concern a disorderly house, but one of conspiring to corrupt public morals. ${ }^{258}$ This shows the state of confusion over the nature of the offence of keeping a 'disorderly house' that prevailed;

- Brady \&Ram (1963). ${ }^{259}$ The appellants were charged with keeping a disorderly house ${ }^{260}$ for giving striptease performances at a revue bar they were the proprietor and manager of. The prosecution alleged (following Quinn, see above) that the performances amounted to an outrage of public decency or tended to deprave or corrupt, or both. Unfortunately, there was no detailed analysis of the offence on appeal. However, Parker CJ noted the need for persistent use, stating: 'That 'keeping' under certain statutes, eg. the Disorderly Houses Act, 1751, and the Gaming Houses Act, 1854, involves some element of persistent use is clear: see Marks v Benjamin...per Parke $B^{261}$ and Davies ${ }^{262}$... While the present proceedings are

\footnotetext{
${ }^{254}$ [1962] 2 QB 245. The first private members striptease clubs started in 1958 (Raymond Revue Bar).

${ }^{255}$ At pp 254-5, Ashworth J simply declared 'In our opinion, while a disorderly house may in some instances amount to a common nuisance, the latter element is not an essential ingredient in the offence of keeping a disorderly house, and it is unnecessary to consider the question of common nuisances further.' Cf. $\mathrm{n} 245$.

${ }^{256}$ Compare it, for example, to Stephen (in 1883), see $\mathrm{n} 211$ which is more accurate statement of the law (ie. the offences comprised and comprises certain specific types of offence)

${ }^{257}$ [1962] AC 220.

${ }^{258}$ Ashworth J, [1962] 2 QB 245, 255 'In [Shaw v DPP]...the material charge was not that of keeping a disorderly house but of conspiring to corrupt public morals, but in our opinion much of the reasoning of the majority is equally applicable to the present appeals.' Reference was made to $R v$ Rice \& Wilson (1866) 10 Cox's CC 155 (the reference was mis-stated). The case held that, to render persons indictable for keeping a disorderly house (in this case, a brothel), it was unnecessary that the conduct be seen from the exterior of the house. The indictment in this case referred to 'keep and maintain a certain common ill governed and disorderly house...for lucre and gain...to the great damage and common nuisance etc.' (italics supplied).

259 (1963) 47 Cr App R 196.

${ }^{260}$ They were fined $£ 2000$ and ordered to pay certain prosecution costs.

${ }^{261}$ (1839) 5 M \& W 565 (151 ER 239)(the case concerned the Disorderly Houses Act 1751), per Parke B at $\mathrm{p} 569$ 'there must be something like an habitual keeping of it, which, however, need not be at stated intervals; thirdly, it must be public, to which all persons have a right to go, whether gratuitously, or on payment of money, no matter whether paid to the defendant or not, if he knows of the payment. All these are questions to be left to the jury.'

262 [1897] 2 QB 199 (the case concerned the Gaming Houses Act 1854, s 4). Russell CJ at p 202 'it is in my opinion monstrous to say that the case falls at all within the mischief or within the provisions of the statute, which was intended to prevent the user of a house as a gaming house. As far as appears from the case, neither those people nor anybody else had ever played at the house before.'
} 
in respect of an alleged common law offence, the court, without coming to a final decision on the matter, will assume that the same element must be found.' 263

In conclusion, the case of Berg (1927) was wrongly decided. It lacked the elements of: (a) open house (ie. a 'common' house - one to which the public had access); (b) persistency in the disorderly behaviour (cf. Moores $v$ DPP, see 16 and Brady v Ram per Parker CJ in 14); (c) financial gain to the keeper of the house (as stated in all the indictments, for 'lucre'). However, the cases of Quinn and of Brady clearly fell within the concept of a disorderly house, since (a)-(c) were fulfilled.

\section{5. $\underline{\operatorname{Tan}(1983)}$}

In Tan (1983) ${ }^{264}$ the court considered the offence of a 'disorderly house' once more - as well as one or two other issues not relevant to the offence. In this case, $\mathrm{T}$ (a prostitute), for reward, would subject a man in private to bondage etc, in a flat she leased from G. T and G were charged with keeping a disorderly house (G was also charged with living off the earnings of a prostitute). On appeal, the court established the following propositions:

- Parker J observed that 'Many forms of conduct may fall within the scope of the offence and to attempt to establish a universal definition with precision is both undesirable and impossible, $; 265$

- Following Quinn (see 14), for the premises to be a disorderly house, there had to be an element of keeping 'open house' so that members of the public who wished to secure the services provided could resort thereto;

- Following Quinn (see 14), the services must be of such a character they amount to an outrage of public decency or are otherwise calculated to injure the public interest to such an extent as to call for condemnation and punishment. As previously noted (see 14), this was a wholly new formulation of the offence of keeping a 'disorderly house';

- Premises could be a disorderly house where the conduct complained of was between two people in private. Since there were no specific categories of conduct that would merit a charge of keeping a disorderly house, it was for a jury to determine whether the manner (and use) to which the premises were put by $\mathrm{T} \&$ $\mathrm{G}$ were such that they were both keeping a disorderly house;

- The jury should be further directed, the fact the services were provided by a single prostitute to one client at a time and without spectators, did not prevent the house from being a disorderly house. ${ }^{266}$

It is asserted that Tan should not have been brought under the offence of 'disorderly house' but under the Sexual Offences Act ('SOA') 1956, on the basis of a person keeping a brothel (since a prostitute was being paid for rendering sexual services). The reason is that, while a 'disorderly house' most certainly did cover bawdy houses (brothels) in medieval times, this was now covered by legislation, superceding the common law position. If Tan could not have been brought under the SOA 1956, re keeping a brothel, the latter should have been amended - not the common law offence used as 'fallback'. This simply created confusion as to the nature of the latter. The position was the same with Court \& Gu (see 19).

\section{Moores v DPP (1992)}

In Moores $v$ DPP (1992) ${ }^{267}$ the defendant was the licensee of a pub, at which the police watched two performances of a male exotic dancer ${ }^{268}$ the second of which JP's held to be indecent.

- The defendant was charged with that of keeping a disorderly house, ${ }^{269}$ and appealed his conviction;

- On appeal, it was held - to establish the offence - it had to be proved the defendant habitually (or persistently) kept such a house and did so with the knowledge of the use to which the premises were put.

Thus, a house did not become disorderly for this purpose because disorder occurred there on a single occasion. In

\footnotetext{
${ }^{263}$ At pp 201-2.

264 [1983] QB 1053.

${ }^{265}$ At $\mathrm{p} 1062$. indicated for keeping a disorderly house.'

${ }^{267}$ [1992] QB 125.

${ }^{268}$ Today, the reference would be to a male stripper.

${ }^{269}$ He was fined $£ 400$ and ordered to pay $£ 125$ costs.
}

${ }^{266}$ Ibid, pp 1062-3. Cf. $R$ v Stannard (1863) 9 Cox's CC 405 (common bawdy house and disorderly house) and $R$ v Barrett (1863),Ibid, $\mathrm{p} 225$ were not cited to the court. See also Stone, The Justices' Manual (ed GB Kennett, $28^{\text {th }}$ ed, 1895), p 262 who cited them and stated: 'The owner of a house letting it out in different apartments to several young women who use the apartments for the purposes of prostitution, cannot be 
particular, Bingham LJ cited with approval the statement of Parker CJ in Brady \& Ram (1963)(see 14). He also stated:

It is plain that to establish [their case] the prosecution have to prove two things: first that the premises in question were a disorderly house and, secondly, that the defendant kept them... ${ }^{270}$ [Also] it appears to me that the mischief which the common law offence is aimed is the mischief of keeping a house to which members of the public resort for purposes of disorderly recreation...The essence of the mischief is the continuity which exists where the use of premises for a given unlawful purpose becomes notorious. ${ }^{271}$

One would agree. The history of the offence of keeping a disorderly house is that of continuum. That is, regularly keeping a common bawdy house, common inn etc, in which disorderly conduct is performed on more than one occasion (as the indictments indicate, viz. to 'keep and maintain'). The fact that there was uncertainly on this issue in Moores v DPP stems from Berg (1927) as well as a poor understanding of the history of this offence.

\section{Summary - Caselaw 1927- 1992}

It is possible to summarise the caselaw from Berg (1927) to Moores $v$ DPP (1992) as follows; there was confusion over certain matters:

- Open House. There was confusion whether a private house could be a 'disorderly house'. It could. However, the house had to be a 'common'. That is, one to which 'members of the public resort for purposes of a disorderly recreation' (Moores v DPP, per Harman LJ). Thus, Quinn \& Bloom (1962, striptease club), Brady and Ram (1983, striptease revue bar), Moores $v$ DPP (1992) (pub at which male striptease performed) all satisfied this pre-requisite. Berg (1927), however, is problematic since there was no evidence that the public ever visited the house - whether for sex or an exhibition. Further, Tan should have been brought under the SOA 1956, s 33 only, since the 'bawdy house' element in keeping a 'disorderly house' had, manifestly, been superceded by that Act;

- Persistency. There was confusion as to persistency. In Berg (1927) there was no evidence of the same. However, in the other cases there was - save for Moores v DPP (only one performance). Harman LJ in that case stated: 'The essence of the mischief is the continuity which exists where the use of premises for a given unlawful purpose becomes notorious'. This seems indubitably correct - evidenced by the form of the indictments;

- Money. In medieval times, this was a pre-requisite and remains so. Thus, a house to which members of the public were invited, without payment, would not comprise a 'disorderly house' ;

- Sexual Offences. At least since 1927, 'disorderly house' has been limited to sexual offences. This reflects its original nature - an offence of keeping an unauthorized brothel (cf. those authorized in Southwark and Cock Lane). Further, today, sexual mores are much more tolerant (for example, homosexual acts are not illegal per se). Thus, the cases from 1927-1992 (many with perjorative observations by judges) should be reviewed in a modern light. ${ }^{272}$

\section{Labaye (2005)}

In Labaye (2005), the Canadian Supreme Court was concerned with the test of indecency in the context of the prosecution of the owner of a 'swinger's club' for keeping a 'common bawdy-house' for the practice of acts of indecency, contrary to the Criminal Code of Canada. A common bawdy house was defined as:

a place that is (a) kept or occupied, or (b) resorted to by one or more persons, for the purpose of prostitution or the practice of acts of indecency. ${ }^{273}$

It was held that - to establish that conduct was 'indecent' - two matters had to be proved on an objective basis.

- $\quad$ First, that - by its nature - the conduct at issue caused harm or presented a significant risk of harm to individuals or society in a way that undermined or threatened to undermine a value reflected in law (ie. one not based on the individual notions of harm or on the teachings of a particular ideology, but on what society, through its laws and institutions, has recognized as essential to its proper functioning). Examples of harm falling within this limb of the test are: (a) confronting members of the public with conduct that

\footnotetext{
${ }^{270}$ At $\mathrm{p} 132$.

271 Ibid.

${ }^{272}$ [1962] 2 QB 245, 259 per Ashworth J 'We venture to emphasize the danger of multiplying offensive adjectives, the result of which may be to expose the summing-up to criticism which it does not really deserve.'

${ }^{273}$ [2005] 3 SCR 728. This definition is wider than the statutory one of a brothel under English law.
} 
significantly interferes with their autonomy and liberty; (b) pre-disposing others to anti-social behaviour, or (c) physically or psychologically harming persons involved in the conduct. The categories of harm are not closed and the examples given are not integral to the definition of harm.

- Secondly, it must be shown that the harm or risk of harm was of a degree that was incompatible with the proper functioning of society. Formulated in this way, the text satisfies the basic requirements of the criminal law of fair notice to potential offenders and clear enforcement standards to the police.

This Canadian case is interesting. However, it is much more jurisprudentially based that any of the cases (or legal texts) on 'disorderly house' under English law. Thus, its relevancy is not of assistance (nor, indeed, cases from other Commonwealth countries). The English offence needs to be considered in light of its own background including City of London customs. Further, as to whether this offence should be abolished needs to be considered in the light of present English legislation on brothels, sexual entertainment venues etc.

\section{Court \& Gu (2012)}

This case ${ }^{274}$ would seem to be an excellent example of why this common law offence needs to modernised since the case was a waste of taxpayer's money and of judicial time. It never should have been brought since it, manifestly, it did not possess two essential elements required for the offence of a 'disorderly house' - it lacked both 'common' and 'persistence' elements.

- The defendants were charged with keeping a disorderly house. They had rented two properties and had placed adverts in the personal services column of a local newspaper. They offered sexual services to police officers who phoned in response to the adverts. When the police visited they found a scantily dressed woman in one of the properties. However, there were no customers and no woman offering sexual services was seen going to (or from) the house. Further, no complaint was made (or received) by the police vis-à-vis the properties in the neighbourhood;

- The defendants were charged under the Sexual Offences Act 1956, s 33A. ${ }^{275}$ However, the prosecution concluding they could not establish the premises constituted a brothel for the purposes of the enactment and being out of time to charge the summary only offence of being tenants using the premises for the purposes of prostitution ${ }^{276}$ - charged the defendants with keeping a disorderly house;

- The case proceeded on the basis that only one woman was ever offering sexual services at any one time and only one customer was ever, at one time, at the premises at (either) house. Further, that the sexual services did not go further than normal sexual intercourse.

The outcome of this case was fairly predictable. Judge CJ stated:

The researches of counsel have not found anything in the old books which suggest any case where, on facts remotely similar to the present in this case, there has ever been a prosecution, let alone a conviction for the keeping of a disorderly house...We have reached the unhesitating conclusion that the circumstances described here, taken at their highest, were not capable of falling within the scope of the common law offence. The criminality which should have been alleged was that the appellants allowed the premises of which they were tenants to be used for prostitution. That however cannot be an appropriate basis for upholding the use of the common law charge..., 277

He also stated:

an ancient common law offence should not normally be expanded beyond well established parameters by judicial decision...on the evidence available in this case the conviction of the appellants represented a significant widening of the ambit of this ancient offence... ${ }^{278}$

One would agree for the following reasons:

- $\quad$ Regularity. In Moores v DPP (1992), where there was only one performance, Harman LJ noted that 'The essence of the mischief is the continuity which exists where the premises for a given unlawful purpose

\footnotetext{
${ }^{274}$ [2012] 1 Cr App R 36.

${ }^{275}$ Sexual Offences Act 1956, s 33(A)(1) provides that it is an offence for a person 'to keep, or to manage, to act or assist in the management of, a brothel to which people resort for practices involving prostitution (whether or not also for other practices).'

${ }^{276}$ Ibid s 34 (tenant permitting premises to be used as a brothel) it is an offence 'for the tenant or occupier, or person in charge, of any premises knowingly to permit the whole or part of the premises to be used as a brothel.'

${ }^{277}$ At p 502.

${ }^{278}$ Ibid, p 501.
} 
becomes notorious...'. The reflects the wording of older indictments ('keep and maintain' etc.) as well as older caselaw. In Court \& Gu, there was no evidence of the woman having had sex with anyone;

- $\quad$ Statute. The common law offence should not apply where statute more properly regulates the matter. Since the issue was that of prostitution, the Sexual Offences Act 1956 s $33^{279}$ and s 33(1A) were manifestly the appropriate provisions re brothels (if at all) since the common offence of 'disorderly house' (which certainly did cover bawdy houses) is superceded by legislation in this respect;

- Open House. For the purpose of 'disorderly house' the house had to be 'common'. That is, one to which 'members of the public resort for purposes of a disorderly recreation'. It may be that the adverts were sufficient to invite members of the public. However, again, there needed to be evidence of notoriety and continuity, which seems to have been lacking.

The court also appeared to assert that 'disorderly house' would not cover straightforward sex, ${ }^{280}$ on the basis of Tan which does, indeed, intimate this because of the remarks of the judge in the case. However, one would assert that Tan is not correct on this. 'Disorderly house' is not based on the depravity of the acts ${ }^{281}$ and, in medieval times and later (such as the time of Coke), this offence clearly did cover bawdy houses offering the usual sexual services.

In conclusion, Court \& Gu (like Tan) indicates the confusion and uncertainty as to the offence of keeping a disorderly house and why it is ripe for abolition or modernisation.

\section{Archbold (2014)}

Modern legal texts fail - or hardly touch on - the offence of keeping a 'disorderly house', ${ }^{282}$ leaving the statement in Archbold (2014) as being the principal definition. ${ }^{283}$ It states: ${ }^{284}$

A disorderly house is one which is not regulated by the restraints of morality and which is so conducted as to violate law and good order. There must be an element of 'open house' but it does not need to be open to the public at large. ${ }^{285}$ A disorderly house may amount to a common nuisance but it is not an essential ingredient of the offence of keeping a disorderly house.

As to this:

- As previously indicated, the concept of 'open house' is confused - resulting from Berg (1927). The best definition (it is asserted) is that of Harman LJ in Moores $v$ DPP (1992), a house must be a house to which 'members of the public resort for purposes of a disorderly recreation';

- A disorderly house is a common nuisance, being suppressed as such. To state it as Archbold does, is to put the 'cart before the horse'. Thus, it not an element of the offence, but the rationale for it. ${ }^{286}$

Archbold also states:

Where indecent performances or exhibitions are alleged as rendering the premises a disorderly house, it must be proved that matters are there performed or exhibited of such a character that their performance or exhibition in a place of common resort (a) amounts to an outrage of public decency, or (b) tends to corrupt

\footnotetext{
${ }^{279}$ Sexual Offences Act 1956, s 33 (keeping a brothel) provides that it is an offence for a person 'to keep a brothel, or to manage, or act or assist in the management of, a brothel.'

${ }^{280}$ At p 501 'In Tan...the entire judgment proceeds on the basis that the provisions of what was described as 'straightforward sexual intercourse'would not be sufficient to constitute the offence.'

${ }^{281}$ See also Quinn (see 14) and Brady \& Ram (see 14) where striptease was sufficient for the purpose of the offence.

${ }^{282}$ This includes Glanville Williams, Textbook of Criminal Law $\left(1^{\text {st }} \mathrm{ed}, 1978,2^{\text {nd }}\right.$ ed 1983, $3^{\text {rd }}$ ed, 2012$)$.

${ }^{283}$ B3.310-3 'It is an offence at common law for a person to keep a disorderly house... This common-law offence is triable either way and when tried on indictment is a class 3 offence...As a common-law offence, punishment is at large by imprisonment and fine, or both... The elements of the common-law offence of keeping a disorderly house were set out in Tan [1983] QB 1053 (a) there must be some element of keeping open house; (b) the house must not be regulated by the restraints of morality, or must be unchaste or of bad repute; (c) it must be so conducted as to violate law and good order. In Moores $v$ DPP [1992] QB 125, it was held that the disorderliness of the house is not confined to sexual behaviour (Berg (1927) 20 Cr App R 38).'

${ }^{284}$ Archbold, n 15, para 20-246.

${ }^{285}$ Berg is cited, see 14.

${ }^{286}$ See eg. $R v$ Williams (1711) 1 Salk 384 (91 ER 334). Husband and wife indicted for keeping a bawdy house (in latin, commun.domun lenocinii). 'keeping a bawdy house is a nuisance and the indictment for keeping is a charge against them for this nuisance...the keeping here is the governing and managing a house in such a disorderly manner.' Case also reported at $10 \operatorname{Mod} 62$ (88 ER 626). See also $R v$ Dixon and his Wife (1715) 10 Mod 335 (88 ER 753). An indictment will lie against a man and his wife for keeping a gaming house. The court at $\mathrm{p} 754$ 'The keeping of a gaming-house is an offence indictable at common law as a nuisance.' See also Comyns, n 28, (1792 ed), vol 4, pp 685-6.
} 
or deprave, or (c) is otherwise calculated to injure the public interest, so as to call for condemnation and punishment. These ingredients should not, however, be regarded as mutually exclusive and a performance may well offend in all three respects. ${ }^{287}$

This wording - derived from Quinn and DPP v Shaw - tends to obscure the true nature of the offence which was one of keeping a brothel. One which was then extended to unauthorised common gaming houses, common cockpits etc., by reason of their also being a nuisance (injurious) to the general public. However (it is asserted) Archbold correctly limits this offence to sexual matters which is what it is primarily concerned about in modern times. ${ }^{288}$

In conclusion, over time, the offence of keeping a disorderly house has become uncertain and confused. Thus, it is ripe for re-evaluation.

\section{Should the Offence Be Retained?}

Keeping a 'disorderly house' has had a long history and the key nature of the offence has been lost sight of.

- It seems clear that 'disorderly houses' were, originally, unauthorised bawdy houses (including common inns and taverns were prostitution also occurred). Thus, the offence was designed to punish prostitution and, doubtless, it would have been one of 'keeping a brothel' or 'keeping a bawdy house', if those words had been in use in early medieval times;

- As to whether this offence is worth retaining, the best way to determine this is to consider all the matters within its ambit over the centuries and whether these are now covered by legislation or other common law offences.

\section{(a) Disorderly House: Non-Sexual}

These are very few indeed.

- Common Inn - Lodging. It may be that a common inn which unreasonably refused to provide board and lodging to a traveller was treated as a disorderly house. However, I have found no evidence of this since 1465 when this offence may have been first recognized. ${ }^{289}$ It any case, today, this offence is treated as a separate criminal offence. Further, it has been asserted that this offence is obsolete (it is also adequately covered by a civil remedy); ${ }^{290}$

- Common Inn - Haunt of Thieves. It seems likely that a common inn (as well as a common tavern) could be indicted for being a disorderly house when it permitted persons of evil fame (ie. criminals) to 'haunt it' (ie. frequent it regularly) (see 6). However, there appears to have been no precedents since - at least when Dalton first wrote in 1618. ${ }^{291}$ Such an offence, today, is dealt with in local legislation (see 12(c)), which legislation, it is asserted, is also obsolete;

- Common Houses - Cockfighting \& Unlawful Games. Cockfighting was banned in England and Wales by the Cruelty to Animals Act 1835. Today, it would be an offence under the Animal Welfare Act 2006. The legislation of 1541 on unlawful games ${ }^{292}$ was repealed in 1960. Thus, this offence does not need to cover such matters today;

- Common Gaming Houses. Gaming is now regulated by the Gaming Act 1968 and other gaming and betting legislation; ${ }^{293}$

- $\quad$ Theatres. The Disorderly Houses Act 1751 has been repealed and theatres are now regulated by the Theatres Act 1968 and other legislation. ${ }^{294}$

In conclusion, this offence is not worth retaining, vis-a-vis non sexual matters. Further, if this sub-category of common nuisance were abolished, any common law matters would still be covered by the common law offence of common nuisance.

\footnotetext{
${ }^{287}$ Quinn and Bloom is cited, see $\mathbf{1 5 .}$

${ }^{288}$ For comments on evidence and the mode of trial, see Archbold, n 15, paras 20-27-8.

${ }^{289}$ See 9(a). Indeed, I have found no evidence prior to that date either.

${ }^{290}$ See McBain, $\mathrm{n} 4$.

${ }^{291}$ That is, I cannot find any cases since 1618 at least. Further, I cannot find any legal text such as Hawkins, Russell etc citing any.

${ }^{292}$ See $n 141$.

${ }^{293}$ See Halsbury, Statutes $\left(5^{\text {th }}\right.$ ed), vol 13.

${ }^{294}$ Ibid.
} 


\section{(b) Disorderly House: Sexual}

- Brothels (Male and Female). The Sexual Offences Act 1956 (amended) makes it an offence to 'keep' a brothel (male or female) or to manage (or act or assist in the management of) a brothel to which people resort to for the purposes of prostitution (whether or not also for other practices). Thus, legislation now covers what was, in olden times, the 'keeping' of a disorderly house (whether a brothel per se or a common inn, tavern etc in which prostitution also went on). As a result, the offence of keeping, or maintaining, a 'disorderly house' has been superceded, in this respect, by legislation; ${ }^{295}$

- Sexual Entertainment Venue. The Local Government (Miscellaneous Provisions) Act 1982 (Control of Sex Establishments) (the '1982 Act'), Sch 3, s 2A controls sex establishments. These comprise sexual entertainment venues, ${ }^{296}$ sex cinemas and sex shops. ${ }^{297}$ Its effect is that - any strip club where live entertainment takes place more than 11 times a year - must apply for a licence from its local authority. ${ }^{298}$ Section $2 \mathrm{~A}$ refers to 'any premises at which relevant entertainment is provided before a live audience for the financial gain of the organiser or the entertainer.' Thus, this now covers 'disorderly house' cases such as: (a) Berg (homosexual exhibition to members of the public for money); ${ }^{299}$ (b) Quinn and Bloom, Brady $\&$ Ram and Moores $v$ DPP (striptease in clubs, bar and pub). ${ }^{300}$ Section $2 \mathrm{~A}$ also covers lap dancing, pole dancing and other adult entertainment - although there has never been a 'disorderly house' case in respect of the same;

- Adultery \& Fornication. These are no longer crimes (whether heterosexual or homosexual). Thus, any London custom and/or inclusion in the concept of 'disorderly house' no longer applies. This also covers the possible ambit of Berg (1927). ${ }^{301}$

Is there any 'disorderly house' case that would not be covered?

- The 1982 Act covers 'premises'. This covers any 'house' - whether public or private - for the purpose of the offence of keeping a 'disorderly house'. The Act also refers to 'financial gain'. Thus, it covers the same as 'lucre or gain' under the 'disorderly house' offence;

- What neither the 1982 Act - nor the common law offence of a keeping a 'disorderly house' - cover is sexual acts open to the public where there is no payment. For example, 'swingers' being invited to a private house to watch (or participate in) sexual acts where no payment is involved. However, it is contended that 'disorderly house' could never cover this in any case - since payment was always a requisite for this offence. ${ }^{302}$

Should this be covered? If so, then legislation should provide separately for it (or it is covered by the offence of outraging public decency). Abolishing the offence of 'disorderly house' will not affect this in any way. In conclusion, the offence of 'disorderly' house, re sexual matters, is now governed by legislation.

Consideration should be given to abolishing the antiquated offence of keeping a disorderly house on the basis it is now covered by more modern offences.

\footnotetext{
${ }^{295}$ That said, the Sexual Offences Act 1956, s 33 and s 33A1 should be amended to clarify the position on certain matters, see 22. See also Caldwell v Leech (1913) 29 TLR 458 where Avory J cited with approval Wills J holding a 'bawdy house' to be the same as a brothel in Singleton v Ellison [1895] 1 QB 607.

296 2A"Meaning of "sexual entertainment venue" It provides, inter alia, (1) In this Schedule "sexual entertainment venue" means any premises at which relevant entertainment is provided before a live audience for the financial gain of the organiser or the entertainer. (2) In this paragraph "relevant entertainment" means - (a ) any live performance; or (b) any live display of nudity; which is of such a nature that, ignoring financial gain, it must reasonably be assumed to be provided solely or principally for the purpose of sexually stimulating any member of the audience (whether by verbal or other means).

${ }^{297}$ Ibid, sch 3(3) \& 4 (sex cinema and sex shop).

298 (3)The following are not sexual entertainment venues for the purposes of this Schedule - (a) sex cinemas and sex shops; (b) premises at which the provision of relevant entertainment as mentioned in sub-paragraph (1) is such that, at the time in question and including any relevant entertainment which is being so provided at that time - (i) there have not been more than eleven occasions on which relevant entertainment has been so provided which fall (wholly or partly) within the period of 12 months ending with that time; (ii) no such occasion has lasted for more than 24 hours; and (iii) no such occasion has begun within the period of one month beginning with the end of any previous occasion on which relevant entertainment has been so provided (whether or not that previous occasion falls within the 12 month period mentioned in sub-paragraph (i)); (c) premises specified or described in an order made by the relevant national authority.

${ }^{299}$ See 14. However, as noted, the activities in Berg may not have been for money and the house never seems to have been visited by any member of the public.

${ }^{300}$ Ibid.

${ }^{301}$ On the assumption the case was of a private invitation to attend a private house for homosexual activity, without payment.

${ }^{302}$ See n 222.
} 


\section{Conclusion}

It is asserted the common law offence of keeping a disorderly house - one which has become uncertain and confused over the centuries - should be abolished. The reasons are simple:

- Common Nuisance. It looks likely that the Law Commission will advise on the retention of the general offence of common nuisance. ${ }^{303}$ Since the offence of keeping a 'disorderly house' is simply a sub-category of common nuisance, if the latter were retained, the offences in 21(a) could still be prosecuted (theoretically) as a common nuisance. One says 'theoretically' since - in reality - these matters are now covered by legislation or are obsolete; ${ }^{304}$

Outraging Public Decency. The whole area of sexual offences is confused and congested, with no less than 73 offences, effectively, set out in a criminal code (the SOA 2003) ${ }^{305}$ as well as old common law offences of: (a) keeping a disorderly house; (b) conspiring to outrage public decency; (c) conspiring to corrupt public morals; and (d) outraging public decency. It is asserted that none of (a)-(c) are needed. Further, it would useful for the legislation on brothels to be simplified, with SOA, ss 33 and 33(1) being consolidated. Also, it being clarified that a place can be brothel even if: (i) there is only one prostitute there; (ii) there is only one client there at a time; (iii) the premises comprise part of a building or a room (including a rented one); (iv) this is the first occasion of prostitution. ${ }^{306}$ It should also be an offence to advertise a brothel or sexual services - save where legislation provides otherwise (such as in the case of sexual entertainment venues).

In conclusion, the common law offence of keeping a 'disorderly house' should be abolished. There is no need of it, since (i) brothels; and (ii) sexual entertainment venues of a public nature, are now regulated by legislation. Further, 'disorderly houses' was never intended to cover other than 'common' houses. If abolished, this would leave no lacuna in the law. ${ }^{307}$

\footnotetext{
303 One would agree with this.

304 The problem with 'disorderly house' started with Higginson (1762) - which should otherwise have been prosecuted under the Act of 1541 as an unlawful game (as was Howel (1675)). This extended the concept. Hawkins then (un-intentionally) further did so - by juxtaposing common gaming houses, playhouses etc together with material on common inns and bawdy houses - and then retaining this, even when legislation was to govern them. Had this not been done, keeping a 'disorderly house' would retained its basic nature, comprising a reference to a brothel. Finally, when the SOA 1956, s 33 was enacted, the opportunity should have been taken to abolish the offence of keeping a'disorderly house' and amending s 33, where necessary.

305 In Court $v$ Gu, [2012] 1 Cr App R, at p 501, Judge CJ noted that: The Sexual Offences Act 2003 is vast and, taking into account the number of provisions from earlier sexual offences Acts which were not repealed, apparently, comprehensive legislation, identifying the vast number of different activities which constitute sexual crime. Counsel reminded us that there are now 35 different statutory provisions which relate to what can loosely be described as the sex trade. ${ }^{, 305}$

306 These are issues which cropped up in Tan and Court \& Gu. See J Card \& J English, Police Law (13 ${ }^{\text {th }}$ ed, 2013) (commenting on SOA 1956, s 33) at p 887, 'It is not necessary to show that some of the people resorting to the premises are prostitutes or that they received payment for their services, but there must be at least three people who use the premises in this way. It does not matter that one of them is the occupier, and it does not matter that only two people at a time ever use the premises for sexual activities.' Cf. Caldwell v Leech (1913) 29 TLR 458.

${ }^{307}$ It is also asserted that the common law offences of: (a) conspiring to corrupt public morals; and (b) conspiring to outrage public decency should also be abolished and that of outraging public decency should become a statutory offence.
} 


\section{Appendix A}

Below are listed cases since 1626 which have been commonly cited by the courts and legal writers in the context of the offence of keeping a disorderly house (in respect of those in italics, the charge was not that of keeping a disorderly house, as such).

$\begin{array}{ll}\frac{\text { Year }}{1626} & \text { Case } \\ 1702 & \text { Wheelhouse } \\ 1706 & \text { Pierson }\end{array}$

1711 Williams

1715 Dixon \& his Wife

1762 Higginson

1787 J'Anson v Stuart

1823 Rogier \& Humphrey

1839 Marks $v$ Benjamin

1866 Rice \& Wilson

1884 Jenks $v$ Turpin

1897 Davies

1927 Berg

1962 Quinn \& Bloom

1963 Brady \& Ram

1983 Tan

\section{Type of Disorderly House}

Man fined for frequenting a suspected bawdy house. ${ }^{308}$

No indictment at common law for adultery (per Holt CJ). ${ }^{309}$

Indictment cannot be maintained against anyone for being a ' $b a w d$ ' and procuring ill-disposed persons to meet and commit fornication. Judgment of being a bawd reversed. Indictment ought to have been that of keeping a common bawdy house. ${ }^{310}$

Indicted for keeping a common bawdy house. ${ }^{311}$

Indicted for keeping a gaming house (not described as a disorderly house). ${ }^{312}$

Common house for 'lucre and profit' for cock fighting, boxing, playing at cudgels and misbehaving. ${ }^{313}$

An indictment for keeping a common bawdy house must state the place where the house is situate and time. Unnecessary to prove who frequents the house. If any unknown persons are proved to be there behaving disorderly, this is sufficient. ${ }^{314}$

Common gaming house for 'lucre and gain' for the playing of rouge et noir. ${ }^{315}$

Disorderly Houses Act 1751. ${ }^{316}$

Kept a brothel (a 'common ill governed and disorderly house') 'for lucre and gain'. Held, unnecessary for conduct to be seen from the exterior of the house for the offence to be committed. $^{317}$

Gaming Houses Act 1854, s $4^{318}$

Gaming Houses Act 1854, s 4 (one event only in a private house). ${ }^{319}$

Private house. Probably, case concerns homosexual play/exhibition to which certain members of the public were to be invited, with payment, and probably sexual activity. Disorderly house. $^{320}$

Striptease in club. Disorderly house. ${ }^{321}$

Striptease in revue bar. Disorderly house. ${ }^{322}$

Leased flat with bondage sessions provided by prostitute. Disorderly house. ${ }^{323}$

\footnotetext{
${ }^{308}$ Note there was no prosecution of the keeper of the house in this case. Thus, it is in italics. It was cited by Blackstone, see $\mathrm{n} 183$.

309 See n 192.

${ }^{310}$ Ibid.

311 See $n 286$

${ }^{312}$ Ibid. See also Bacon, n 26, vol 5, title 'Nuisances' pp 146-7 (it contains a useful summary in 1798).

313 See n 162

${ }^{314}$ See $n 200$.

${ }^{315}$ See $n 236$.

${ }^{316}$ See $n 261$.

${ }^{317}$ See n 258.

${ }^{318}$ See n 236.

319 See n 262.

${ }^{320}$ See 14.

${ }^{321}$ See $n 254$.

${ }^{322}$ See n 259.

${ }^{323}$ See 15. The fact that services were provided by a single prostitute to one client at a time without spectators did not prevent the house being a disorderly house. It is asserted this should have prosecuted (if at all) under the SOA 1956.
} 
1992 Moores v DPP Striptease (male exotic dancer) in pub. Only one performance held to be indecent. Insufficient regularity to comprise a disorderly house. ${ }^{324}$

2012 Court \& Gu Leased flat with 'straightforward' sex offered by prostitute. Not a disorderly house. ${ }^{325}$

\section{Copyrights}

Copyright for this article is retained by the author(s), with first publication rights granted to the journal.

This is an open-access article distributed under the terms and conditions of the Creative Commons Attribution license (http://creativecommons.org/licenses/by/3.0/).

${ }^{324}$ See 16.

${ }^{325}$ See 19. This case, in part, proceeded on the same basis as Tan (services provided to one client at a time and only one customer at the house without spectators). It is asserted that it should have prosecuted (if at all) under the SOA 1956. 